\title{
Steinalderkeramikken fra Rogaland - en kronologisk studie
}

\begin{abstract}
From the 1800's and onwards, pottery sherds have been found at a number of Neolithic occupation sites in Rogaland County, Southwestern Norway. In this paper, pottery assemblages from nine contexts are analyzed in order to produce an interpretative chronology. Typological analysis is combined with correspondence analysis and Bayesian modelling of radiocarbon dates. The result is a coherent chronological model that accounts for variations in pottery decoration styles between the late Early Neolithic and the Late Neolithic. There is a development in decorative styles from cord and cord-stamp ornamented vessels followed by a period of pots decorated with cord-stamp, small imprints and incisions, and finally a phase with added lines, comb, and cord-stamp. However, the multi-phased nature of the sites suggests that there are still many unanswered questions. New excavations and re-analyses of older sites are necessary for a better understanding of the developments in Neolithic pottery styles.
\end{abstract}

\section{Innledning}

De eldste keramiske krukkene man kjenner til i Norge, opptrer i Finnmark rundt 5500 f.Kr., og er av typen kamkeramikk (Skandfer 2005). Den hittil eldste leirfiguren forestiller en sel, og er funnet på boplassen Nøstvet (5000 f.Kr.) i Ås (Akershus/Viken) (Jaksland 2005). Ettersom en keramisk håndverkstradisjon likevel ikke oppsto på Østlandet i eldre steinalder, er det først innen sørnorsk neolitikum (3900-1700 f.Kr.) man ser etableringen av den. Den eldste keramikken på Østlandet og i Agder, fra perioden 3900-3500 f.Kr., er primært knyttet til keramiske tradisjoner som eksisterte innenfor den eldste jordbrukende gruppen i Sør-Skandinavia, den såkalte Traktbegerkulturen (Glørstad 2009; Glørstad og Sundström 2014; Østmo og Skogstrand 2006; Sørensen 2014). Impulser fra Traktbegerkulturen kan trolig spores omkring Oslofjorden frem til $2800 \mathrm{f}$.Kr. Allerede rundt $3500 \mathrm{f}$.Kr. ble keramikkhåndverket utbredt også på Vestlandet, og der blant folk man antar levde hovedsakelig som jegere, fiskere og sankere (Olsen 1992; Østmo 2010; 2008). Dette håndverket, der krukker dekorert med snorstempelornering er et kjennetegn, fortsatte gjennom mellomneolittisk tid (3300-2350 f.Kr.) og trolig et stykke inn i senneolittisk tid (2350-1700 f.Kr). Ved overgangen til bronsealderen forsvinner det sporløst.

Dette var den korte og grove versjonen av historien til det eldste keramikkhåndverket i Sør-Norge. I realiteten er den langt mer kompleks, men det har vist seg utfordrende for 
arkeologer å oppnå en bedre forståelse av utviklingen, blant annet grunnet materialets fragmenterte tilstand (ingen hele krukker er bevart), og fordi de færreste forskere har hatt tid og ressurser til å studere hele det sørnorske keramikkmaterialet samlet, noe det i realiteten fortjener. I denne artikkelen presenterer jeg et mindre bidrag i denne retning ved å under-

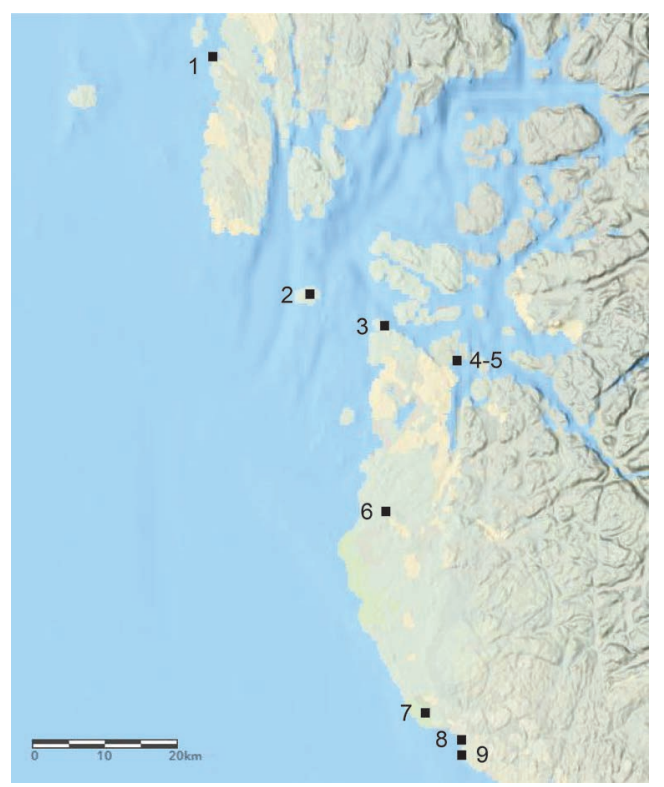
søke den stilistiske utviklingen innen neolittisk keramikk funnet i Rogaland fylke. Jeg skal se nærmere på keramiske funn, dvs. skår, fra ni lokaliteter spredt geografisk fra Karmøy i nord til Hå i sør (figur 1, tabell 1). Metoden som anvendes, kalles «fortolkende kronologi» (Bayliss mfl. 2013a, 2013b), og den kombinerer typologisk analyse av gjenstandsmateriale med korrespondanseanalyse og modellering av radiokarbondateringer. Resultatet fra denne studien er en ny kronologisk modell for stilutviklingen innen neolittisk keramikk fra Rogaland.

Figur 1. Den moderne topografien $i$

Rogaland og de undersøkte lokalitetene,

1: Helganes. 2: Kvitsøy 3. 3: Logavik.

4: Austbø 12A. 5: Austbø 12B. 6. Holeheia.

7: Rugland. 8: Slettabø. 9: Lego.

Tabell 1. De undersøkte lokalitetene.

\begin{tabular}{|c|c|c|c|c|c|c|c|}
\hline Kommune & Lokalitet & G & N & N dekorert & Magring & Bunnformer & Referanse \\
\hline Karmøy & Helganes & 1482 & 515 & 122 & $\begin{array}{l}\text { Kvarts, } \\
\text { glimmerkvarts }\end{array}$ & $\begin{array}{l}\text { Avrundet, sterkt } \\
\text { svungen, rett }\end{array}$ & Solberg 2015 \\
\hline Kvitsøy & Kvitsøy 3 & - & 12 & 1 & Bergart & - & Dugstad mfl. 2018 \\
\hline Randaberg & Logavik & - & 126 & 18 & $\begin{array}{l}\text { Feltspat, } \\
\text { bergart }\end{array}$ & - & Løken 1977 \\
\hline Stavanger & Austbø 12A & - & 922 & 115 & $\begin{array}{l}\text { Feltspat, } \\
\text { bergart }\end{array}$ & - & Juhl 2001 \\
\hline Stavanger & Austbø 12B & - & & & $\begin{array}{l}\text { Feltspat, } \\
\text { bergart }\end{array}$ & Spiss & Juhl 2001 \\
\hline Klepp & Holeheia & - & 1633 & 146 & - & Spiss & Skjølsvold 1980 \\
\hline Hå & Rugland & & 274 & 1 & Bergart & - & Lindblom 1982 \\
\hline Hå & Slettabø & 43025 & 9876 & 1103 & Bergart, grog & $\begin{array}{l}\text { Flat, avrundet, } \\
\text { spiss }\end{array}$ & Skjølsvold 1977 \\
\hline Hå & Lego & - & 89 & 12 & - & - & Skjølsvold 1977 \\
\hline
\end{tabular}




\section{Keramikken og dekoren}

Det finnes et knippe studier som har lagt grunnlaget for stilistiske analyser av sørnorsk steinalderkeramikk, hvorav Arne Skjølsvolds (1977) analyse av Slettabø og Einar Østmos (2008) analyse av Auve fremstår som sentrale verk. På grunnlag av disse møysommelige materialstudiene, samt en rekke mindre, men fortsatt svært viktige publikasjoner (f.eks. Amundsen 2000; Glørstad 1996; Ingstad 1965; 1970; Nummedal og Bjørn 1930), mener jeg dekorelementene på den sørnorske neolittiske keramikken kan organiseres $\mathrm{i}$ åtte hovedgrupper: snor, linjer (inkludert innriss), inntrykk av cardiumskjell, små inntrykk (inkl. kløftet redskap, pinnestikk, groper), kamstempel, snorstempel, og vulst (dvs. pålagte lister). Blant disse hovedgruppene av dekortyper er snorstempelet det hyppigst forekommende i Sør-Norge, og særlig gjelder dette på skårene som er funnet på de mellomneolittiske lokalitetene (3300-2350 f.Kr.).

I en tidligere gjennomgang av gjenstandsmaterialet på sørnorske neolittiske lokaliteter hevdet vi at utførelsen av snorstempeldekoren kan oppsummeres i 10 hovedgrupper (Figur 2) (Nielsen mfl. 2019). Disse gruppene er selvsagt også relevante for materialet fra Rogaland, selv om noen kommentarer er nødvendige. Blant annet er typen CS8, som viser til enkle eller doble rader med Y-formede mønster under randen, kun kjent på Østlandet og langs Skagerrak-kysten, deriblant på lokalitetene Auve, Rødskjær og Bota (figur 3) (Ingstad 1970; Østmo 2008). Denne stilen er derfor utelukket fra foreliggende analyse. Typene CS7 og CS9 viser begge til vertikale inntrykk av snorstempel plassert inn mot knekken på buken til krukkene. I denne studien har jeg lagt dem sammen til én gruppe, kalt CS7/9. Det kan også nevnes at typen CS10, som kan se ut som skrå linjer med snorstempel, egentlig viser til løst plasserte linjer, som i litteraturen ofte kalles «grissent» eller «glissent» snorstempel (Glørstad 1996; Skjølsvold 1977:354, pl. 44, 2 p, II, 20/30).

Å fokusere analysen på de enkelte bestanddelene i materialet er et første ledd i en polytetisk klassifikasjon, en metodisk tilnærming som først ble drøftet av David Clarke (1968). I korthet viser det til en forståelse av materialet hvor hver enhet, i dette tilfellet hver lokalitet (eller hvert stratigrafisk definert lag) med tilhørende gjenstandsfunn, er definert ut fra en
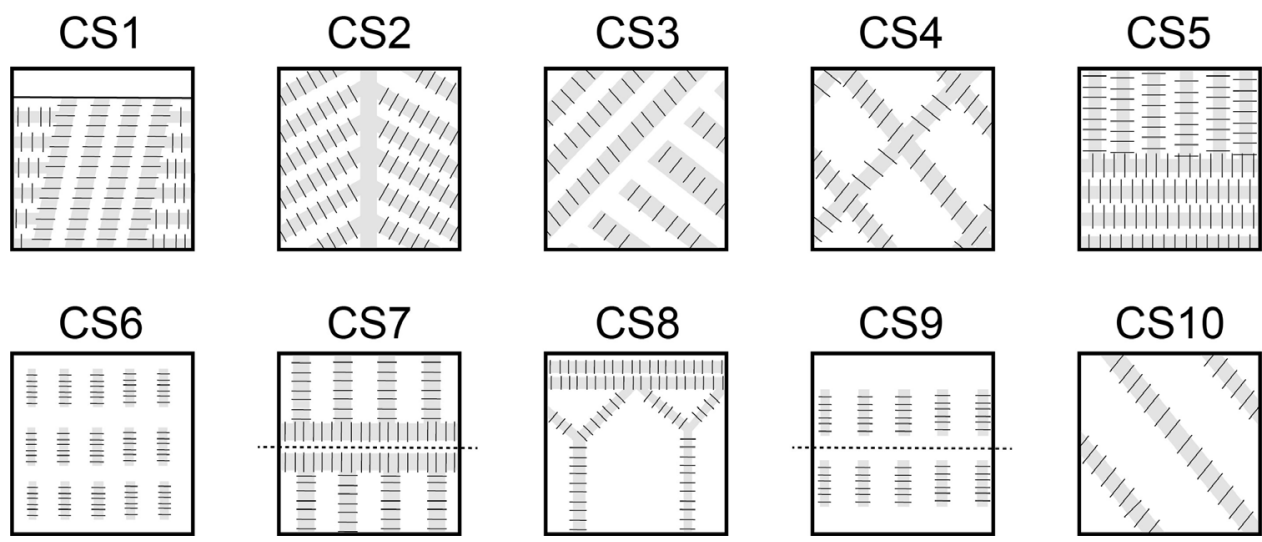

Figur 2. De ulike mønstrene av snorstempel på keramikk funnet på neolittiske boplasser i Sør-Norge. 


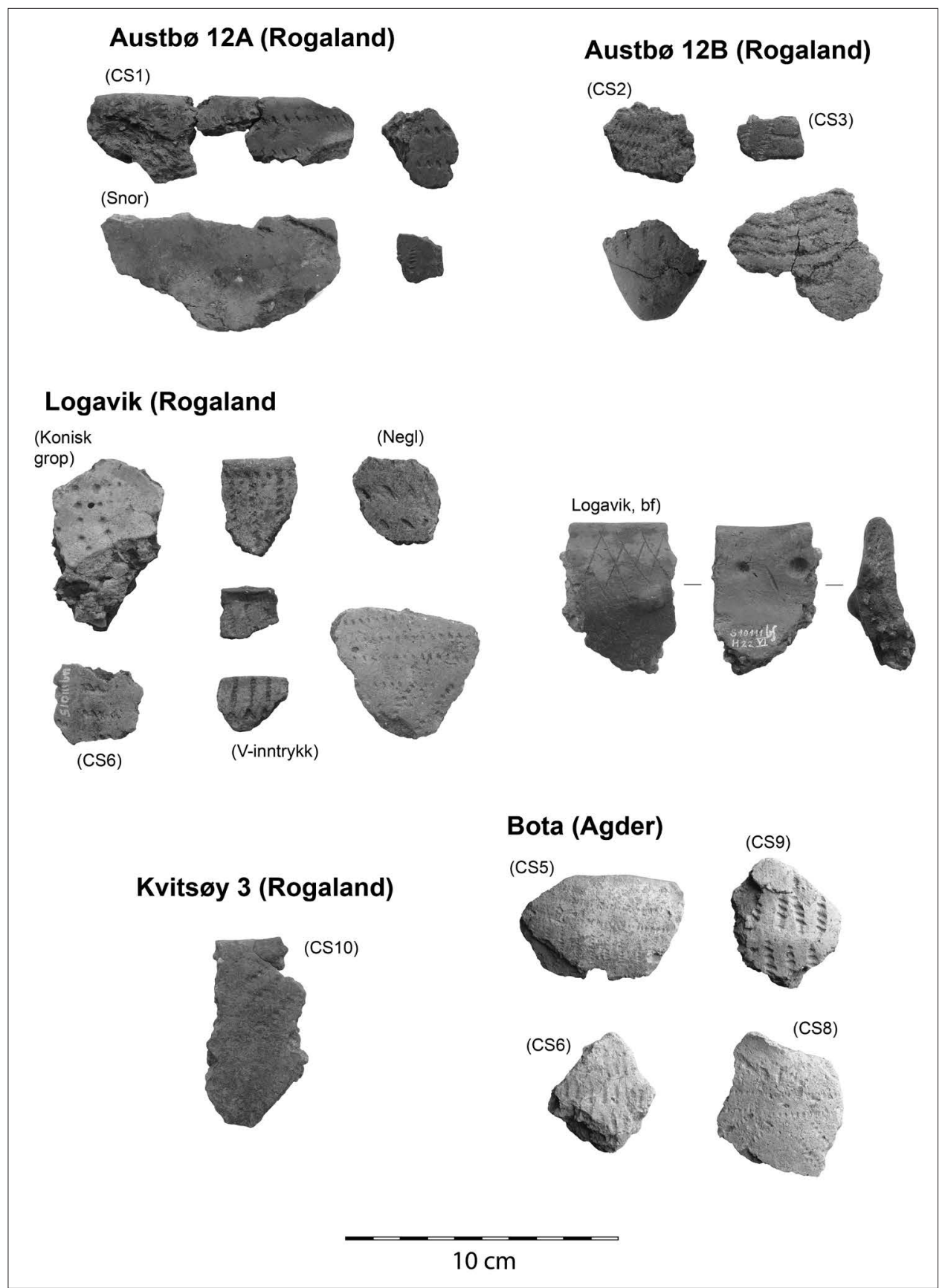

Figur 3. Et utvalg dekorerte skår fra lokalitetene i Rogaland, samt fra lokaliteten Bota $i$ Arendal. Skåret merket bf) fra Logavik viser til funnets navn i tilveksten. Alle foto er tatt av forfatteren. 


\begin{tabular}{|c|c|c|c|c|c|c|c|c|c|}
\hline Kommune & Lokalitet & $\begin{array}{l}\text { Prøve } \\
\text { samlet inn }\end{array}$ & Prove ID & $\begin{array}{l}\text { Alder før } \\
\text { nåtid }\end{array}$ & $\begin{array}{l}\text { Standard- } \\
\text { avvik }\end{array}$ & Alder f.Kr. & Kontekst & Materiale & Referanse \\
\hline Stavanger & Austbø 12A & 1987 & T-8365 & 5290 & 70 & 4321-3972 & Grøft & Kull & Juhl 2001 \\
\hline Stavanger & Austbø 12A & 1987 & $T-8443$ & 4860 & 100 & $3938-3375$ & Kokegrop & Kull & Juhl 2001 \\
\hline Stavanger & Austbø 12A & 1987 & T-8438 & 4760 & 60 & $3649-3375$ & Kulturlag & Kull & Juhl 2001 \\
\hline Stavanger & Austbø 12A & 1987 & T-8437 & 4220 & 90 & $3082-2501$ & Ildsted & Kull & Juhl 2001 \\
\hline Stavanger & Austbø 12B & 1987 & T-8439 & 4540 & 90 & $3517-2934$ & Kulturlag & Kull & Juhl 2001 \\
\hline Stavanger & Austbø 12B & 1987 & T-8444 & 4500 & 80 & $3488-2926$ & Kulturlag & Kull & Juhl 2001 \\
\hline Stavanger & Austbø 12B & 1987 & T-8366 & 4300 & 110 & $3336-2620$ & Kulturlag & Kull & Juhl 2001 \\
\hline Karmøy & Helganes & 2011 & Beta-319748 & 4870 & 30 & 3706-3634 & Teltring 2, Lok D & Kull & Solberg 2015 \\
\hline Karmøy & Helganes & 2011 & Tra-3219 & 4180 & 30 & $2887-2666$ & Tuft 1 & Nøtteskall & Solberg 2015 \\
\hline Karmøy & Helganes & 2011 & Tra-3222 & 4175 & 30 & $2885-2638$ & Tuft 2 & Nøtteskall & Solberg 2015 \\
\hline Karmøy & Helganes & 2011 & Beta-291199 & 4140 & 40 & 2876-2586 & Lag & Kull & Solberg 2015 \\
\hline Karmøy & Helganes & 2011 & Beta-291198 & 4100 & 40 & 2871-2497 & Tuft 2 & Nøtteskall & Solberg 2015 \\
\hline Karmøy & Helganes & 2011 & Tra-3221 & 4100 & 30 & $2863-2503$ & Lag & Nøtteskall & Solberg 2015 \\
\hline Karmøy & Helganes & 2011 & Tra-3220 & 4095 & 30 & 2861-2501 & Tuft 1, ildsted & Nøtteskall & Solberg 2015 \\
\hline Karmøy & Helganes & 2011 & Tra-3224 & 4045 & 30 & $2834-2475$ & Tuft 3 & Nøtteskall & Solberg 2015 \\
\hline Karmøy & Helganes & 2011 & Tra-3218 & 4015 & 30 & $2618-2470$ & Tuft 1 & Nøtteskall & Solberg 2015 \\
\hline Karmøy & Helganes & 2011 & Beta-291197 & 3960 & 40 & $2576-2340$ & Kulturlag i myr & Nøtteskall & Solberg 2015 \\
\hline Karmøy & Helganes & 2011 & Beta-291196 & 3900 & 40 & $2481-2212$ & Tuft 1 (prøvestikk) & Nøtteskall & Solberg 2015 \\
\hline Karmøy & Helganes & 2011 & Beta-291195 & 3610 & 40 & 2131-1881 & Tuft 1 & Kull & Solberg 2015 \\
\hline Klepp & Holeheia & 1962 & T-391 & 4590 & 110 & $3636-3015$ & Fase 1, ildsted & Kull & Nydal mfl. 1964 \\
\hline Klepp & Holeheia & 1962 & T-588 & 4490 & 120 & $3517-2899$ & $\begin{array}{l}\text { Fase 3, bunn av } \\
\text { ildsted }\end{array}$ & Kull & Gulliksen mfl. 1978 \\
\hline Klepp & Holeheia & 1962 & T-587 & 4470 & 120 & $3515-2888$ & $\begin{array}{l}\text { Fase 3, bunn av } \\
\text { ildsted }\end{array}$ & Kull & Gulliksen mfl. 1978 \\
\hline Klepp & Holeheia & 1962 & T-1782 & 4400 & 130 & $3499-2679$ & Fase 1, lag & Kull & Gulliksen mfl. 1978 \\
\hline Klepp & Holeheia & 1962 & T-392 & 4400 & 100 & $366-2876$ & Fase 1, lag & Kull & Nydal mfl. 1964 \\
\hline Klepp & Holeheia & 1962 & T-1783 & 3410 & 120 & $2023-1445$ & Fase 3, lag & Kull & Gulliksen mfl. 1978 \\
\hline Randaberg & Logavik & 1977 & T-2687 & 4250 & 90 & $3261-2574$ & Ildsted & Kull, løvtre & Tilvekst S10111 \\
\hline Randaberg & Logavik & 1977 & T-2688 & 4060 & 50 & 2861-2472 & Ildsted & Kull, løvtre & Tilvekst S10111 \\
\hline Randaberg & Logavik & 1977 & T-2689 & 3000 & 90 & 1441-979 & Ildsted & Kull, løvtre & Tilvekst S10111 \\
\hline Ogna & Slettabø & 1963 & T-1803 & 4820 & 180 & 3989-3095 & $\operatorname{Lag} 3$ & Kull & Gulliksen mfl. 1978 \\
\hline Ogna & Slettabø & 1963 & $T-560$ & 4780 & 130 & $3491-3118$ & $\operatorname{Lag} 3$ & Kull & Gulliksen mfl. 1978 \\
\hline Ogna & Slettabø & 1963 & T-738 & 4730 & 100 & $3712-3122$ & $\operatorname{Lag} 3$ & Kull & Glørstad 1996 \\
\hline Ogna & Slettabø & 1963 & $T-561$ & 4650 & 100 & $3641-3098$ & $\operatorname{Lag} 2$ & Kull & Gulliksen mfl. 1978 \\
\hline Ogna & Slettabø & 1963 & T-1779 & 4640 & 130 & $3691-2945$ & $\operatorname{Lag} 3$ & Kull & Gulliksen mfl. 1978 \\
\hline Ogna & Slettabø & 1963 & T-1780 & 4470 & 120 & $3515-2888$ & $\operatorname{Lag} 3$ & Kull & Gulliksen mfl. 1978 \\
\hline Ogna & Slettabø & 1963 & $\mathrm{~T}-627$ & 3970 & 100 & $2865-2200$ & $\operatorname{Lag} 2$ & Kull & Glørstad 1996 \\
\hline Ogna & Slettabø & 1963 & T-628 & 3860 & 100 & 2581-2027 & $\operatorname{Lag} 2$ & Kull & Glørstad 1996 \\
\hline Ogna & Slettabø & 1963 & T-739 & 3790 & 70 & $2459-2036$ & $\operatorname{Lag} 2$ & Kull & Glørstad 1996 \\
\hline
\end{tabular}

Tabell 2. Dateringer fra de undersøkte lokalitetene. 
mer eller mindre hyppig forekomst av ulike særtrekk (se nyere diskusjon i Furholt 2019). Man tar altså utgangspunkt i materialets variasjon, heller enn én enkeltdel på bekostning av de andre. Det motsatte av polytetisk klassifikasjon er monotetisk klassifikasjon, der man forutsetter et sett med enheter som hver analysert lokalitet eller kontekst skal passe inn i.

Monotetisk klassifikasjon har blant annet vært utbredt i forskningen på neolitikum i SørSkandinavia, hvor arkeologiske lokaliteter kunne klassifiseres som tilhørende en bestemt kultur, for eksempel Traktbegerkultur eller Gropkeramisk kultur. Denne tradisjonen er blitt kritisert i nyere forskning, nettopp fordi det har vist seg nærmest umulig for studier av den neolittiske keramikken å bryte seg løs fra de eldre (monotetiske) studiene, som var en del av fagets tradisjonelle kulturkretslære (Glørstad 2006; Furholt 2019). En av de mest innflytelsesrike forskerne innen denne skolen var den danske arkeologen C.J. Becker, som i 1947 postulerte at spredningen av slipte flintøkser på Jæren og i Oslofjord-området vitnet om en innvandring av jordbrukere i tidligneolittisk tid, og at keramikkfunnene «som antagelig vil dukke op en skønne Dag», ville kunne vise eksakt hvilke Sør-Skandinaviske bygder de første bøndene i Rogaland slektet til (sitert fra Becker 1947:199). Becker selv nevnte NordJylland som en mulig parallell, og denne modellen blir diskutert senere i denne artikkelen.

\section{Materialet}

Lokaliteter som er inkludert $i$ analysen

De neolittiske lokalitetene fra Rogaland som egner seg til foreliggende analyse, er, fra nord til sør i fylket, Helganes, Kvitsøy 3, Logavik, Austbø 12 A og B, Holeheia, Rugland, Slettabø og Lego (tabell 1-3) (Dugstad mfl. 2018; Juhl 2001; Lindblom 1982; Løken 1977; Skjølsvold 1977; 1980; Solberg 2015). I de typologiske analysene av dekorstiler har jeg selv dokumentert keramikken fra Austbø-lokalitetene, Logavik og Kvitsøy 3 (figur 3). I de andre tilfellene har jeg basert meg på tidligere beskrivelser, analyser og avbildninger. Av størst betydning for den kronologiske analysen har lokalitetene med radiokarbondateringer vært (tabell 2). Alle dateringer er blitt kalibrert på ny i denne artikkelen med den nyeste tilgjengelige kalibreringskurven (Bronk Ramsey 2021; Reimer mfl. 2020).

De arkeologiske undersøkelsene som har samlet inn det analyserte materialet, ble foretatt over et langt tidsrom, fra de første undersøkelsene på Holeheia på 1800-tallet til de relativt nylige undersøkelsene på Helganes i 2011 og Kvitsøy i 2015 (Gustafson 1899; 1906:35; Solberg 2015; Dugstad mfl. 2018). Holeheia ble undersøkt igjen av Skjølsvold (1980) i 1962, og i den sammenheng ble en serie kullprøver datert innenfor perioden mellomneolitikum A (3300-2800 f.Kr.). Noen har stilt seg kritiske til disse dateringene fordi de fremstår som «for tidlige» sammenlignet med gjenstandsmaterialet. Skjølsvold (1977:244) var selv kritisk, og mente keramikken måtte stamme fra «en sen fase av båtøkskulturen». Solberg (2015:89) har også nylig argumentert for at hovedaktiviteten på Holeheia, i et typologisk perspektiv, burde dateres til 2600-2300 f.Kr. I tabell 1 har jeg notert forekomsten av spissbunnede kar på Holeheia, som er avbildet hos A.W. Brøgger (1909:6), og som også nevnes av Helge Gjessing (1920:75).

To år før undersøkelsen på Holeheia hadde Skjølsvold foretatt en mindre undersøkelse på lokaliteten Lego i Hå. Skjølsvold (1977:239) har kalt stedet for «Nygård», men jeg har valgt å bruke lokalitetsnavnet Lego i denne sammenheng ettersom dette er mer kjent i litteraturen. På Lego ble en del keramikkskår funnet i et kulturlag innenfor en rektangulær 
hustuft, hvorfra kullprøver ble datert til yngre bronsealder; 900-590 f.Kr. (2620 \pm 80 BP) og 750-405 f.Kr. (2430 \pm 90 BP). Skjølsvold tolket keramikkfunnene som rester etter en eldre bosetning på stedet, altså fra neolittisk tid, en tolkning jeg har basert meg på i denne studien.

Året etter utgravningen av Holeheia undersøkte Skjølsvold (1977) den svært funnrike boplassen på Slettabø i Hå, som lå bare noen steinkast fra boplassen på Lego. I likhet med dem fra Holeheia ble også dateringene fra kulturlagene på Slettabø gjenstand for diskusjon, og en grundig forståelse av sammenhengen mellom dateringene og kulturlagene ble først presentert av Glørstad (1996). Som Glørstad påpekte, skal dateringen T-561 (4650 $1100 \mathrm{BP}$, 3641-3098 f.Kr.) som ble samlet inn fra lag 2, nok tolkes som representativ for aktiviteten i det eldre lag 3, og denne tolkningen er implementert i foreliggende analyse. På grunnlag av en serie dateringer av matskorper samlet inn fra skår fra Slettabø, argumenterte Glørstad også for at deler av materialet fra lag 3 kunne være enda eldre enn det kulldateringene indikerte. Særlig ett skår, dekorert med horisontal og vertikal snorstempelornering, funnet i rute 4 p i lag 3 og med datering av matskorpe til 4245-4045 f.Kr. (Tua-651, 5305 \pm 80 BP), ble fremhevet av Glørstad (1996:47) som en indikator på at «tradisjonen med keramikk har mesolittiske røtter også i Sør-Norge». Dateringen skulle plassere krukken i fase 4 av mesolitikum. Om man kalibrerer dateringen ved å korrigere for et marint etterslep i karbonkretsløpet, tilsvarende den som er målt for Atlanterhavet i nyere tid, dvs. 380 \pm 30 år (Mangerud mfl. 2006), dateres krukken til rundt 3800 f.Kr. Også denne alderen er tidligere enn antatt ut fra kulldateringene fra lag 3 alene.

Tolkningen til Glørstad om at deler av keramikken fra lag 3 på Slettabø kan stamme fra mesolittisk tid, er også styrket av det daterte skårets S-formede profil, som ofte går igjen på krukkene innenfor den sørskandinaviske Ertebølle-kulturen. Forekomsten av Ertebølleinspirert keramikk på Slettabø skulle også kunne fungere som en logisk forklaring på hvorfor spissbunnede kar forekommer noen århundrer senere på mellomneolittiske lokaliteter, deriblant på Austbø 12B (figur 3). Imidlertid er det de senere årene også blitt funnet tidligneolittiske krukker i Øst-Sverige med samme S-formede profiler, og tilnærmet tilsvarende utførelse av snorstempel, eksempelvis på boplassen Skogsmossen (type Vrå IV, i Hallgren 2008:168). Derfor vil jeg argumentere for at modellen til Glørstad fortsatt er plausibel, men at den trenger mer data for å gjøre den overbevisende, samtidig som kalibrering av daterte matskorper fortsatt er knyttet til særskilte metodiske utfordringer (Philippsen 2012; 2013). I denne studien har jeg derfor valgt at det konservative utgangspunktet at kulldateringene, ikke matskorpedateringene, må danne rammene for alderen til lagene på Slettabø.

Boplassen Logavik i Randaberg ble undersøkt i 1977 (Løken 1977; boplassen er omtalt som «Mekjarvik» i Solberg 2015:89), men er dessverre ikke blitt presentert i detalj av nyere forskning. Området hvor undersøkelsen foregikk, var blitt dyrket i nyere tid. De fleste artefaktene fra undersøkelsen ble funnet i pløyelaget, og rester av et kulturlag med tre ildsteder under pløyelaget ble undersøkt i et rutenett. Det ble også samlet inn 81 fragmenter av brente bein, inkludert et tåledd fra bjørn og et mulig fragment fra småfe. Disse beinene er ikke daterte.

Resultatene fra undersøkelsene på Rugland i 1977-78 er grundig presentert og tolket av Inge Lindblom (1982; se også Simonsen, Lindblom og Bakkevik 1982). Rugland-boplassen hadde en «uvant» lokalisering høyt oppe i en skråning, 130 moh., på en av de øverste lavlandsgårdene på Sør-Jæren (Lindblom 1982:16). Boplassen var relativt godt bevart fordi en gravhaug var blitt anlagt på stedet i jernalderen. Gjenstandsmaterialet og keramikken ble datert til senneolitikum på grunnlag av en kulldatering av et ildsted. 
I likhet med Logavik er heller ikke Austbø-lokalitetene, som ble undersøkt i 1987, presentert i forskningsøyemed (rapporter publisert i Juhl 2001). Lok. 12A og B på Austbø lå i utmark, og var del av samme boplassflate, som var delt $\mathrm{i}$ to av et moderne gjerde. Lok. 12B lå også noe lavere i landskapet, og muligheten for en noe yngre alder enn 12A er også reflektert i dateringene fra kullprøver. Lokalitetene har trolig vært strandbundne i neolitikum, da aktiviteten fant sted.

De seineste undersøkelsene som har bidratt til innsamlingen av det analyserte materialet, har foregått på Helganes på Karmøy i 2011 og på Kvitsøy i 2015 (Dugstad mfl. 2018; Solberg 2015). Materialet fra Helganes ble grundig bearbeidet og presentert av Solberg (2015), og jeg har tatt utgangspunkt i dette arbeidet når det gjelder faseinndeling av dateringer og dekor på keramikk. På Kvitsøy 3 ble det funnet kun 12 skår, hvorav ett var dekorert, og dette materialet forekom på en lokalitet med spor etter boplassaktivitet i senmesolitikum og tidligneolitikum (Dugstad mfl. 2018). Skårene fra Kvitsøy 3 er sannsynligvis yngre enn boplassaktiviteten, men det foreligger ikke utgravningsdata som kan tidfeste skårene mer nøyaktig enn det.

\section{Lokaliteter som er ekskludert fra analysen}

I tidligere forskning er flere lokaliteter i Rogaland med sikker eller med mulig steinalderkeramikk nevnt. Blant førstnevnte er R20 Gjedlestadvika, som ble undersøkt på Eigerøy i 1971 (Bang-Andersen 1981). Materialet fra R20 er i sin helhet godt beskrevet av Sveinung Bang-Andersen (1981), men det keramiske materialet stammer trolig fra ulike faser av neolitikum, og det er behov for flere dateringer for at dette materialet skal kunne brukes i mer detaljerte kronologiske studier (diskutert i Olsen 1992:144-145).

Blant lokalitetene med mulig steinalderkeramikk kjenner man blant annet til Bonshidleren (katalognummer S6786 i tilveksten) i Hjelmeland, hvor tilveksten forteller om funn av skår dekorert med «punktornamenter, fremkalt ved inntrykning av pinner». Pinneinntrykk er blant annet kjent fra tidligneolittisk keramikk (type Volling), men også fra mellomneolittisk keramikk fra Sør-Norge (Østmo 2008). Det foreligger en datering fra Bonshidleren til 2122-1635 f.Kr. (Tua-2856, 3530 \pm 75 BP), og denne er rapportert som gjort på bein av sau eller geit. Det innsamlede materialet fra Bonshidleren ser derfor ut til å være flerfaset, og lokaliteten er ikke inkludert i denne studien, selv om det er en mulighet for at keramikken kan være neolittisk.

I tillegg til de ovennevnte lokalitetene kjenner man til de såkalte «verkstedspladse» eller «flintmarker» på Jæren, altså steder hvor det ble gjort funn av flintgjenstander på 1800-tallet og tidlig 1900-tall, hvor det også var funnet keramikk. Gjessing nevner flere slike steder hvor det var gjort funn av skår laget av «simpel, grov masse» (f.eks. Gjessing 1920:125). Et av de bedre beskrevne funnstedene er Oskebrotet i Randaberg, hvor Bjørlykke (1908:141142) ved en mindre undersøkelse fant «et sort lag, der indeholdt kulrester, flintskjærver, benstumper og potteskaar». Funnene ble klassifisert av Brøgger, som skilte ut 44 skår fra minst ett spissbunnet kar, magret med kvarts og feltspat. Jeg har ikke lykkes å gjenfinne funnstedet på Oskebrotet. Bjørlykke (1908:133) nevnte også funn av «brudstykker av krukker av simpelt, grusblandet, brændt ler» fra stedet Gåsen i Sele, og dette funnet ble nærmere beskrevet av H. Gjessing (1914) noen år senere. En mer nøye empirisk gjennomgang av materialet fra både Oskebrotet og Gåsen er høyst nødvendig dersom disse lokalitetene skal inngå i studier av kronologi. 


\section{Metode}

\section{Fortolkende kronologi}

Begrepet fortolkende kronologi er i denne studien en direkte oversettelse av det engelske begrepet «interpretative chronologies» (Bayliss mfl. 2013a). Fortolkende kronologi er en konkret fremgangsmåte eller metode til å danne kronologiske oversikter basert på et arkeologisk materiale når man har tre kildekategorier tilgjengelige: 1) gjenstander som kan klassifiseres typologisk, 2) flere gjenstandstyper fra flere lokaliteter (eller kontekster) som kan analyseres med korrespondanseanalyse, og 3) radiokarbondateringer som belyser alderen til de relevante lokalitetene eller kontekstene. Metoden for å danne fortolkende kronologier er nøye beskrevet i en rekke studier av Alex Bayliss mfl. (2013a; 2013b; 2013c) av jernaldergraver i England, og det er deres presentasjon(er) jeg vil ta utgangspunkt i her.

Metoden fortolkende kronologi er fortolkende fordi hver enkelt del, altså typologi, korrespondanseanalyse og kalibrering av dateringer involverer forenklinger av et arkeologisk materiale som i utgangspunktet er svært komplekst. Metoden er også fortolkende fordi man i praksis jobber parallelt med de ulike metodene frem og tilbake, ved å gjøre justeringer og gjerne nye tolkninger, helt til man har en modell som gir mening, og som ikke er motsigende. Dette gjelder overraskende nok i mindre grad for den typologiske analysen, fordi identiteten til arkeologiske gjenstander sjelden skifter etter at de først er blitt gjenstand for klassifikasjon.

For korrespondanseanalysen er det fortolkende elementet faktisk mer relevant, fordi vekting av data og valg av visuell presentasjon avhenger av en rekke faktorer. Korrespondanseanalyse er en utbredt metode i arkeologisk forskning, blant annet takket være programmet CAPCA, som er blitt utviklet spesielt for arkeologer (Madsen 2014), men primært fordi den er godt egnet for en bedre forståelse av endring over tid i et arkeologisk materiale. Det skal dog nevnes at korrespondanseanalysens nøyaktighet avhenger av materialets nøyaktighet, og boplassdata er ansett som problematisk nettopp fordi materialet kan stamme fra ulike forhistoriske perioder (Arnold 1985; Koch 1998; Sørensen 2014:117). En måte å ta hensyn til denne kritikken på er å være åpen om hvilke tidsrammer materialet muliggjør, og å produsere modeller som følger disse faktorene. I denne studien har jeg brukt programmet CAPCA (Madsen 1990; 2014). Dette fungerer i praksis som en såkalt ad-in i Excel, og det utfører analyser basert på data plottet i spredningsark, hvor objekter er linjer og variabler er kolonner i skjemaet.

Kalibrering av dateringer innenfor metoden fortolkende kronologi er også en fortolkende praksis, fordi målet er å utføre kalibreringer som tar hensyn til tolkninger av arkeologiske kontekster, og det daterte materialets egenart (se blant annet Glørstad og Solheim 2015; Nielsen 2020). Kalibrering i henhold til restriksjoner som vi pålegger materialet, er mulig å utføre gjennom ulike funksjoner i kalibreringsprogrammet OxCal (Bronk Ramsey 2018; 2021). Disse modellene, i OxCal kalt «phase» og «sequence», tar i bruk en matematisk modell som først ble formulert av presten og matematikeren Thomas Bayes (1763). Betydningen av denne modellen, som kalles Bayes' teorem, innenfor sannsynlighetsberegning er blant annet grundig forklart på norsk av Stoltenberg (2017), og det finnes en rekke internasjonale studier som gir en detaljert introduksjon i hvordan Bayes' teorem implementeres i kalibreringer av radiokarbondateringer (Bayliss 2015; Bayliss mfl. 2007; Buck og Meson 2015; Litton og Buck 1995; Steier og Rom 2000). 
Restriksjonene som er pålagt det foreliggende materialet, er først og fremst tolkningen at hver datert kullprøve representerer en hendelse i forhistorien, og videre at dateringene fra hver lokalitet representerer hendelser innenfor et bestemt tidsspenn. Målet med den bayesianske analysen er å tidfeste starten og slutten på dette tidsspennet, forutsatt at deponeringsforløpet av materialet som er datert, fordeler seg jevnt i tid (Buck mfl. 1992). Det ligger i denne metodens natur at nye data vil kunne implementeres og gjøre modellen mer robust og presis, eventuelt demonstrere at modellen må omformuleres og tolkes på ny (Bayliss 2015:680).

\section{Resultat}

Korrespondensanalysen av dekorerte keramikkskår

Resultatet av den typologiske analysen av keramikkskårene er presentert i tabell 3 . Korrespondanseanalysen utført i programmet CAPCA av dataene i denne tabellen gir et plot med en romlig spredning av objekter (lokaliteter) som overensstemmer med en utvikling over tid (figur 4). Det er den andre prinsipielle aksen som representerer tid, mens den første prinsipielle aksen representerer variasjon. I hvor stor grad utviklingen korresponderer med dateringene, diskuteres i neste kapittel.

Den utviklingen vi ser i plottet, «starter» med Austbø 12A nede til venstre og «slutter» med Rugland og Kvitsøy 3 nede til høyre. At lokalitetene er spredt i en tilnærmet bueform, tyder på at analysen har fanget opp et mønster som viser overlapping av fenomener over tid. At lokalitetene Austbø 12A og deretter Slettabø lag 3 starter utviklingen i materialet, gjenspeiles i forekomsten av snorornerte skår, og disse lokalitetene har også C-14-dateringer til tidligneolitikum. Deretter følger Austbø 12B etterfulgt av et gap i spredningen før Holeheia, Logavik og Helganes opptrer relativt samlet. Både Austbø 12B og Holeheia har dateringer innenfor perioden mellomneolitikum A (3300-2800 f.Kr.), mens Logavik og Helganes har dateringer fra første halvdel av det tredje årtusen f.Kr.

Som nevnt har tidligere studier argumentert for at aktiviteten i Holeheia er flere århundrer yngre enn det dateringene tilsier, og nedenfor kommer jeg inn på gode holdepunkter for dette i det presenterte materialet. Likevel er det også trekk som støtter dateringene, blant

Tabell 3. Data for dekorelementer på keramikkskår på de undersøkte lokalitetene.

\begin{tabular}{|l|c|c|c|c|c|c|c|c|c|c|c|c|c|c|c|c|}
\hline Lokalitet & Snor & Kryss & Negl & Kam & $\begin{array}{c}\text { Pinne- } \\
\text { stikk }\end{array}$ & Bein & $\begin{array}{c}\text { Konisk } \\
\text { grop }\end{array}$ & Vulst & CS1 & CS2 & CS3 & CS4 & CS5 & CS6 & CS7/9 & CS10 \\
\hline Helganes & 0 & 1 & 0 & 0 & 1 & 1 & 1 & 0 & 0 & 0 & 1 & 0 & 1 & 1 & 1 & 0 \\
\hline Kvitsøy 3 & 0 & 0 & 0 & 0 & 0 & 0 & 0 & 0 & 0 & 0 & 0 & 0 & 0 & 0 & 0 & 1 \\
\hline Logavik & 0 & 1 & 1 & 0 & 0 & 0 & 1 & 0 & 1 & 0 & 1 & 0 & 1 & 1 & 0 & 0 \\
\hline Austbø 12A & 1 & 0 & 0 & 0 & 0 & 0 & 0 & 0 & 1 & 0 & 0 & 0 & 0 & 0 & 0 & 0 \\
\hline Austbø 12B & 0 & 0 & 0 & 0 & 0 & 0 & 0 & 0 & 0 & 1 & 1 & 0 & 0 & 0 & 0 & 0 \\
\hline Holeheia & 0 & 1 & 0 & 0 & 1 & 0 & 1 & 0 & 1 & 1 & 0 & 1 & 1 & 0 & 0 & 0 \\
\hline Rugland & 0 & 0 & 0 & 0 & 0 & 0 & 0 & 1 & 0 & 0 & 0 & 0 & 0 & 0 & 0 & 1 \\
\hline Slettabø lag 3 & 1 & 0 & 0 & 0 & 0 & 0 & 0 & 0 & 0 & 1 & 1 & 0 & 0 & 0 & 0 & 0 \\
\hline Slettabø lag 2 & 0 & 1 & 0 & 1 & 0 & 0 & 1 & 1 & 0 & 0 & 1 & 1 & 1 & 1 & 1 & 1 \\
\hline Leg0 & 0 & 0 & 0 & 0 & 0 & 0 & 1 & 0 & 0 & 0 & 1 & 0 & 0 & 0 & 0 & 1 \\
\hline
\end{tabular}




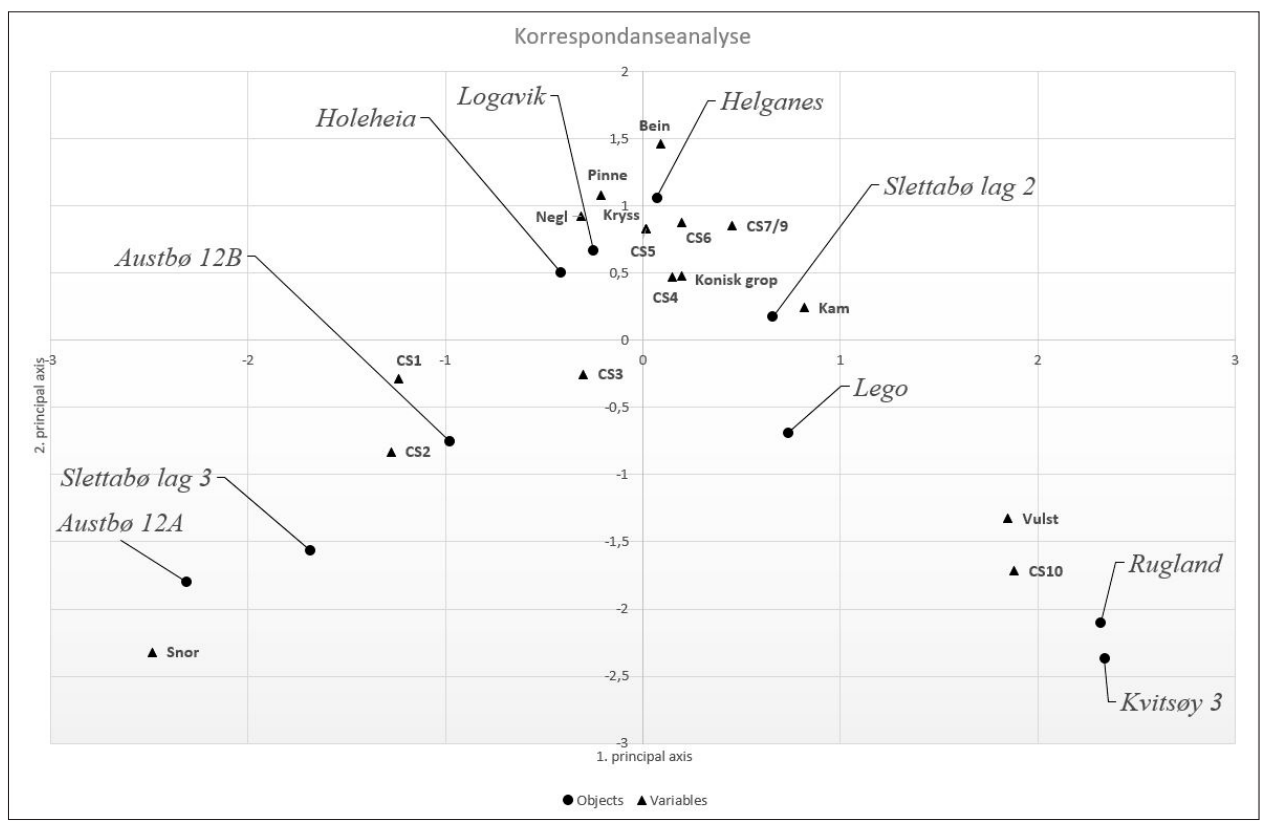

Figur 4. Resultat fra korrespondanseanalysen av dekor på keramikkskår fra de undersøkte lokalitetene.

annet skårene som er dekorert med kryssende snorstempel (CS4). I Rogaland finner vi det kun igjen i lag 2 på Slettabø, og som jeg nevner nedenfor, får dette også konsekvenser for forståelsen av dette laget. Ser man derimot nordover, finner vi kryssende snorstempel på boplassen Kotedalen på Radøy, og da innenfor keramisk hovedgruppe II, som Olsen (1992:129) daterte til tidsrommet 4700-4200 BP (ca. 3400-2800 f.Kr.) basert på en rekke kulldateringer. Ettersom dateringene fra Holeheia er innenfor dette tidsspennet er det ikke umulig at denne stilen, altså snorstempel i kryssende linjer, hører hjemme nettopp der.

Det som knytter skårene fra Holeheia til Logavik og Helganes, som begge har yngre radiokarbondateringer, er blant annet skår dekorert med innriss. De innrissede kryssene er små på skårene fra Holeheia og Helganes, mens de danner et større rutenett av romber på det ene skåret fra Logavik (figur 3). Det som skiller Austbø 12B fra de tre ovennevnte, er nok nettopp bortfallet av små inntrykk og innriss i materialet, som gjør at den plasseres nærmere de eldre lokalitetene i korrespondanseanalysen. Skåret med innriss fra Logavik (figur 3, skår bf) mener jeg er bemerkelsesverdig både grunnet dekoren (rombisk innriss og knopp) og profilet, som er vinklet innover ved munningen. Denne krukkeformen minner om keramikkfunn fra de danske øyene, som dateres til mellomneolitikum periode III-IV (30002900 f.Kr.) (Ebbesen 1980), samt en av krukkene som er funnet på Kjølberg i Østfold/Viken (Resi 1998). Som kjent ble skår fra to forskjellige krukker funnet på Kjølberg, hvorav matskorpen fra den andre krukken (dekorert med koniske groper) ble datert til 2920-2675 f.Kr. (Tua-2144, 4240 \pm 75 BP). Denne dateringen er samtidig med alderen som er indikert av kulldateringene fra Logavik. Selve dekoren på skåret fra Logavik, altså innrissingene under 
randen, har paralleller til neolittiske funn fra Vest-Sverige, blant annet boplassen Haslingehult, som har C-14-dateringer til perioden 3100-2700 f.Kr. (Edenmo mfl. 1997:156). Dette kan tyde på at boplassen Logavik markerer overgangen til det tredje årtusen f.Kr. i materialet som er undersøkt her, og at plasseringen til Holeheia like ved Logavik i korrespondanseanalysen tyder på at deler av materialet derfra også kan høre til denne fasen. Dette styrker også antakelsen til Skjølsvold og Solberg, om at deler av materialet på Holeheia faktisk er yngre enn det C-14-dateringene tilsier.

Det skal også nevnes at det finnes ett skår fra Logavik som ser ut til å være dekorert med små V-formede stempler (figur 3), en type dekor som forekommer på flere skår fra lag 2 på Slettabø (Skjølsvold 1977:361, pl. 51), samt på lokaliteten Solbakken 3 i Idd, Østfold/ Viken (Østmo 2004). Et brent nøtteskall, datert til 2880-2675 f.Kr. (Tua-3801, 4180 \pm 50 BP) fra sistnevnte lokalitet, er tolket av Østmo (2004) som representativ for boplassaktiviteten på Solbakken 3. Dette forsterker inntrykket av at keramikken fra Logavik ble deponert innenfor tidsrommet 3000-2600 f.Kr.

Videre i plottet fra korrespondanseanalysen følger Slettabø lag 2, deretter Lego og helt til slutt Rugland og Kvitsøy 3. Lego trekkes mot de mellomneolittiske lokalitetene på grunn av forekomsten av skår dekorert med koniske groper, som også gjør den mer lik materialet fra lag 2 på Slettabø. Som nevnt ovenfor er det stiler i materialet fra lag 2 på Slettabø som peker bakover i tid. Dette gjelder skårene med kryssende linjer av snorstempel (CS4), i tillegg til parallelle linjer av snorstempel vinkelrett mot hverandre (dvs. CS3 og CS5), som også forekommer på lokaliteter med dateringer fra mellomneolitikum A (3300-2800 f.Kr.).

Spredningen av variabler (dekortyper) i plottet danner også et interessant mønster. Trenden går i svært grove trekk i henhold til disse kategoriene: snor, snorstempel, små inntrykk, kamstempel, vulst og «grissent» snorstempel. Ikke overraskende starter utviklingen med snordekoren, som er typisk for keramikken fra tidligneolitikum (3900-3300 f.Kr.). De få skårene med snorornering danner ikke noe grunnlag for å si at de er eldre enn de snorstempelornerte skårene fra de samme lokalitetene. Glørstad regnet snor som et innslag i både lag 3 og 2 på Slettabø, og det forekom flere skår fra ett kar med vertikal snorornering på Auve, som i henhold til kulldateringene fra lokalitetene ikke kan være stort eldre enn 3300 f.Kr. (Østmo 2008).

I plottet følger deretter en ansamling med tre typer snorstempeldekor, nemlig rette og skråstilte rekker. Kryssende linjer og tette horisontale render som møter like tettstilte vertikale render, opptrer deretter sammen med en rekke ulike typer inntrykk, slike som pinnestikk og koniske groper. Rørknokkel er ikke særlig utbredt i det analyserte materialet, og forekommer utelukkende på Helganes. Tidfestingen synes imidlertid pålitelig, da skår med inntrykk av rørknokkel forekom også på Auve (Østmo 2008), og det er et kjent dekorelement på samtidig keramikk fra Vest-Sverige og de danske øyene (eksempler i Glob 1952; Davidsen 1978; Strinnholm 2001). Koniske groper og kryssende snorstempeldekor forekommer derimot oftere i det undersøkte materialet, og disse viser også til utviklingen mot keramikken fra Slettabø lag 2.

En av de siste stilene av snorstempel, før den senneolittiske CS10, er kombinasjonen jeg har kalt CS7/9. Som nevnt er dette en kombinasjon av to ulike typer utførelse av snorstempel rettet mot knekken på buken til karet. Ikke i noen tilfeller vet vi hvordan disse krukkene har sett ut hele. I presentasjonen av karformene på Slettabø, mente Skjølsvold (1977:75) at karformen $f$ med «tilnærmet S-formet profil med en karakteristisk knekk på buken og stå- 
flate» kun var representert av det ene klokkebegeret fra lag 2. I denne studien viser dekortypen kalt kamstempel kun til dette ene klokkebegeret fra Slettabø. Senere, i behandlingen av dekorstilene på keramikken fra Slettabø, påpekte Skjølsvold (1977:93, 355, pl. 45, 1 p, II, 30/40) likevel at flere av skårene dekorert med snorstempel, av typen som her er definert som CS7, stammet fra kar med en skarpt markert overgang mellom hals og buk, ikke så ulikt karformen $f$ og dermed klokkebegeret.

Selve dekorstilen CS7 har lite å gjøre med de keramiske tradisjonene innen Klokkebegerkulturen. Den er tidligere blant annet godt dokumentert på Auve, hvor den opptrer nettopp på kar med vinklet profil og markert skulder (Østmo 2008:126-130). Slik sett må man kunne si at de sistnevnte skårene fra lag 2 på Slettabø, representerer en tidligere oversett karform på denne lokaliteten, en stil som vi nå også kan registrere som til stede på Helganes (og forøvrig også på Bota i Arendal, og Auve i Sandefjord). I og med at dateringene fra Helganes peker primært mot tidlig mellomneolitikum B (2800-2500 f.Kr.), er det ikke usannsynlig at det finnes en aktivitetsfase på Slettabø fra denne perioden som de daterte kullprøvene fra lag 2 ikke har fanget opp. Den ovenfor nevnte forekomsten av skår med V-formede inntrykk i lag 2 på Slettabø støtter også denne tolkningen, selv om man også kan hevde at denne dekoren kan ha fortsatt inn i perioden sen mellomneolitikum B (2500-2200 f.Kr.). Den første tolkningen virker likevel mer trolig.

Helt i slutten av utviklingen av variablene ved de senneolittiske lokalitetene opptrer vulst og «grissent» snorstempel (CS10) samlet. Korrespondanseanalysen plasserer denne gruppen langt fra midtgruppen av mellomneolittiske lokaliteter, og det er primært grunnet fravær av likhet i materialet. Den ene dateringen fra Rugland tilsier at denne gruppen hører til senneolittisk tid, og vulstkeramikk funnet på boplasser på Østlandet støtter denne tidsplasseringen (Østmo 1993; Reitan mfl. 2018).

\section{Modellering av dateringene}

Resultatet av modelleringen av dateringene i OxCal er vist i figurene 5 og 6 . I kodingen bak modellen som ligger til grunn for disse plottene, har jeg forutsatt at hver fase, det vil si aktiviteten på hver lokalitet $\mathrm{i}$ henhold til tidsrammer bestemt av dateringene, er uavhengig av hverandre. Det vil si at jeg ikke har tolket fasene som strengt følgende etter hverandre i tid, for vi har ikke stratigrafiske eller andre beviser som skulle antyde dette. På Slettabø har vi det, fordi kulturlagene var stratigrafisk adskilt, men tidsrommet mellom lag 3 og 2 er potensielt såpass stort at det ikke gir mening å legge inn en korreksjon for dette i den kronologiske modellen.

I og med at det keramiske materialet fra Rogaland som sådan er dårlig bevart, og vi har relativt få kontekster å analysere med henblikk på det lange tidsrommet som studeres, er det rimelig å anta at ulike dekortyper kan ha vært til stede samtidig på de ulike lokalitetene. For eksempel er ikke dateringene fra Holeheia blitt pålagt noen restriksjoner som skulle argumentere for at disse er yngre enn dateringene fra Austbø 12B, selv om korrespondanseanalysen åpner for en slik tolkning. Fasene er derfor plassert i modellens hierarki i henhold til den kronologiske utviklingen som ble identifisert av korrespondanseanalysen, men uten at vi har pålagt restriksjoner mellom lokaliteter.

Det er de kalibrerte verdiene (her oppgitt med 68,3\% sannsynlighet) etter modelleringen som er vist i figur 5, og i venstre marg står prøvenummer samt to verdier i parentes som skal forklares. Den første verdien (A) viser til i hvor stor grad den individuelle prøvens post- 
Modellerte dateringer

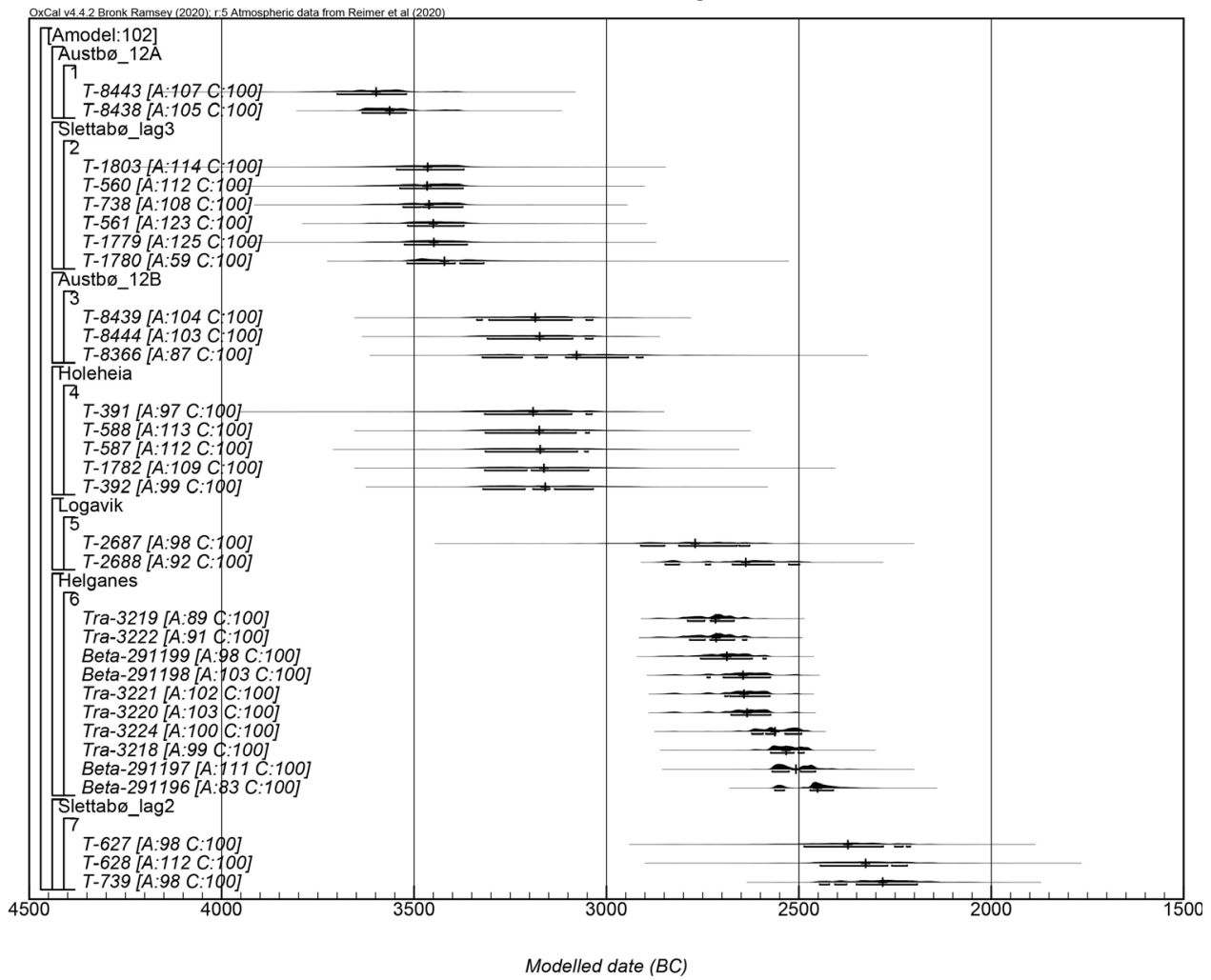

Figur 5. Resultat av statistisk modellering av dateringene fra de undersøkte lokalitetene.

modellerte og kalibrerte verdi overlapper med den pre-modellerte og kalibrerte verdien. Er det en stor overlapping mellom dem, vil denne verdien være oppgitt som rundt $100 \%$ eller mer (Bayliss mfl. 2013c:85). Er den derimot lavere enn ca. $60 \%$, er dette et tegn på at restriksjonene man har pålagt dateringen, ikke er i overensstemmelse med dateringens alder slik den er indikert i prøvens målte BP-verdi med standardavvik. Alle verdiene i den presenterte modellen ligger på rundt 90-100 \%, og de er derfor å regne som i god overensstemmelse med grunndata. Unntaket er prøven T-1780 fra Slettabø lag 3, med verdien A:59. Også Glørstad (1996:44) påpekte at denne dateringen skaper «mest uro» i lagdelingen på Slettabø. Før modelleringen kalibreres T-1780 til 3515-2888 f.Kr., og med tanke på den sikre stratigrafiske plasseringen (i lag 3) på Slettabø skulle man ha god grunn til å anta at modelleringen kan gjenspeile prøvens reelle alder, til tross for et noe lavt utslag på A-indeksen. Derimot kan man også argumentere for at T-1780 ikke skal tolkes i lys av de andre dateringene fra lag 3, men at vi må formulere en ny modell.

Med T-1780 som et indisium på den yngste aktiviteten fra lag 3 blir det mulig å tolke prøven T-561 (4650 100 BP, 3641-3098 f.Kr.) fra lag 2, som Glørstad (1996) mente skulle være knyttet til den eldre aktiviteten, som tilhørende en slik ny modell. Dersom T-561 skal 
Start og slutt

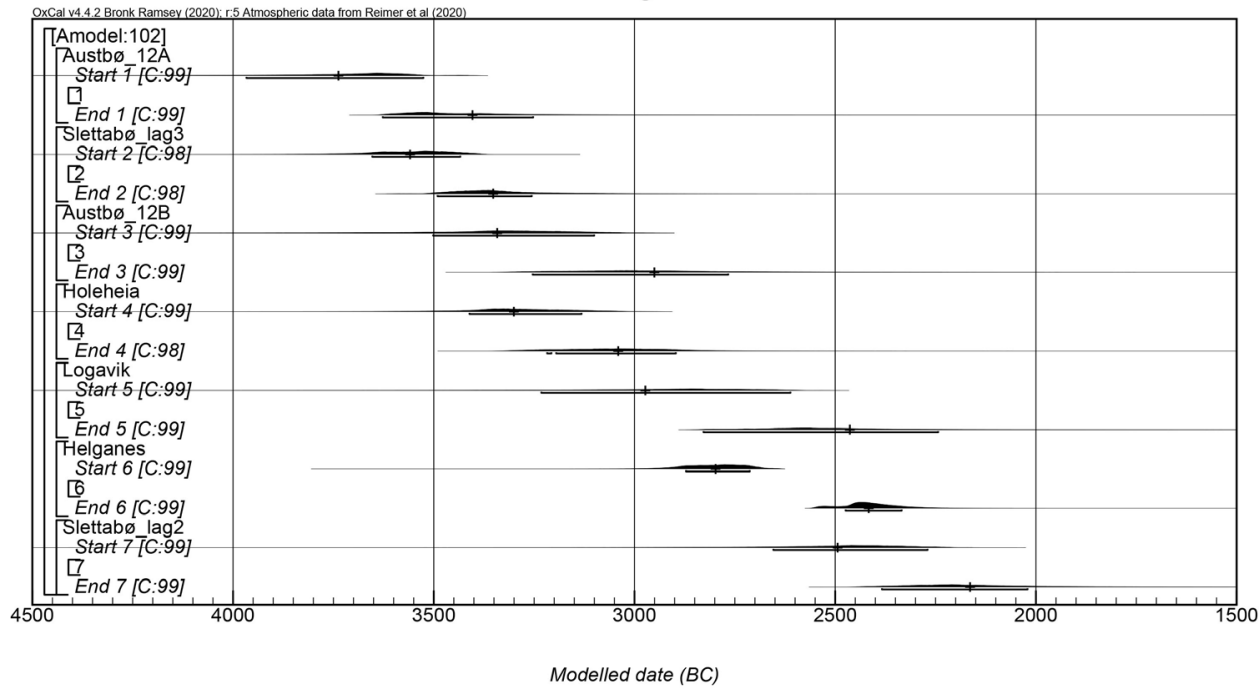

Figur 6. Resultat av statistisk modellering av dateringene fra de undersøkte lokalitetene. Her vises de kalkulerte start- og sluttdatoene for lokalitetene.

tolkes i lys av aktiviteten fra lag 3, bør også laget med flyvesand mellom lag 3 og 2 tolkes som en kortvarig enkelthendelse, og at aktiviteten på lokaliteten må ha fortsatt relativt kort tid etterpå. Figur 7 viser det kalibrerte plottet i OxCal fra prøvene T-1780 og T-561 når vi legger til tolkningen om at prøven fra lag 3 (T-1780) er eldre enn prøven fra lag 2 (T-561). I modellen er «prøve A» fra lag 3 og «prøve $\mathrm{B}$ » fra lag 2. A-verdiene godkjenner modellen, og vi kan med utgangspunkt i denne analysen anta at sandlaget, som jo skiller de to prøvene stratigrafisk, trolig ble dannet rundt 3400-3200 f.Kr., og at aktiviteten har fortsatt etterpå.

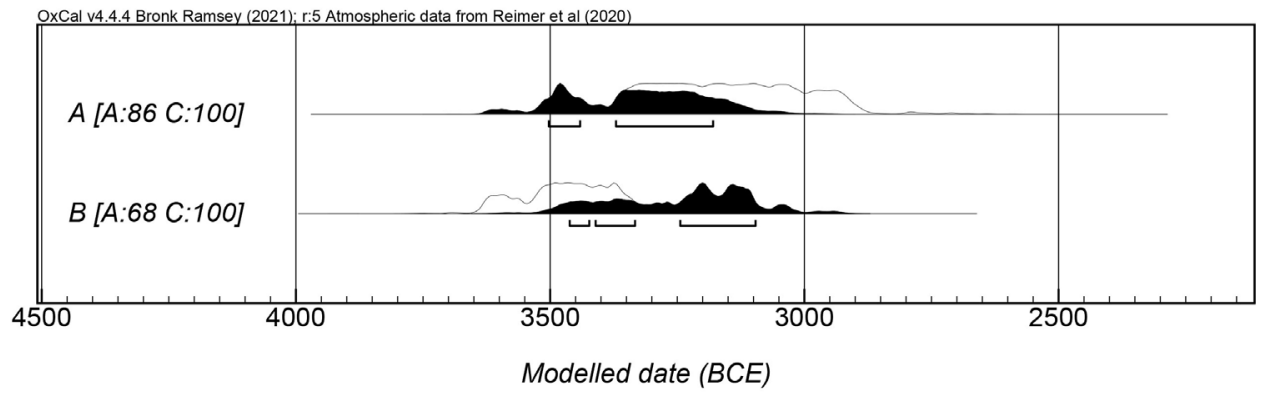

Figur 7. De kalibrerte aldrene til prøvene T-1780 (A) fra stratigrafisk lag 3 på Slettabø og prøven T-561 (B) fra stratigrafisk lag 2. I denne modellen forutsettes det at prøve A er eldre enn prøve $B$, og at sandlaget mellom de stratigrafiske lagene må ha blitt dannet en gang mellom deponeringen av kullet. 
Som argumentert for ovenfor har vi grunn til å tro at keramikk ble deponert på Slettabø også fra ca. 2800 f.Kr. og frem til tiden indikert av serien med dateringer fra lag 2.

Den andre verdien (C) bak prøvenummeret og den nevnte A-verdien, viser til prøvens konvergens, og denne har en kritisk verdi på 95 \%. Kalkuleringen av konvergens er knyttet til antallet foreslåtte kalibrerte aldre $\mathrm{OxCal}$ produserer for hver enkelt datering i hver enkelt modell (Bronk Ramsey 1995). Som Bayliss med kolleger har påpekt, vil en kronologisk modell i OxCal ha for mange individuelle parametere til at en utregning av sannsynlighet $\mathrm{i}$ strengt henhold til Bayes' teorem ikke vil være praktisk mulig (Bayliss mfl. 2013c:84). For å kunne produsere et stort nok antall mulige tolkninger av den kronologiske modellen, bruker OxCal metoden kalt Markov Chain Monte Carlo (MCMC) (Bronk Ramsey 2018). Selv om et relativt stort antall ulike versjoner av modellen produseres i OxCal, gjerne opptil to millioner, vil man kunne se at i modeller med lave A-verdier vil den best rangerte modellen ha kalibrerte dateringer som ikke nødvendigvis er helt like dersom modellen kjøres igjen i programmet. Avviket kan være på 5-10 år, og trenger derfor ikke ha noen reell betydning for hvorvidt den arkeologiske tolkningen som ligger til grunn for modellen, er riktig eller ikke. I vår modell ligger C-verdiene på nærmere 100 \% i alle tilfeller, og dette betyr at programmet mener det har simulert «nok» versjoner av modellen.

På bakgrunn av hver enkelt A-verdi i modellen kalkulerer OxCal også en overordnet indeks for modellen som helhet, kalt Amodel (helt oppe til venstre i figur 5). I likhet med dateringenes A-verdi, skal også verdien til Amodel være over $60 \%$, og helst rundt $100 \%$. Den foreliggende modellen har Amodel:102. Likevel er det ikke slik at A-verdiene viser til ulik sannsynlighet hva angår hvor plausibel modellen man bruker er, men de viser kun til hvor stabil modellen i seg selv er. Det vil si at en Amodel-verdi på 120 ikke gjør en modell mer sannsynlig, med henblikk på den arkeologiske tolkningen, enn en annen modell med Amodelverdi på 80 (Bayliss mfl. 2013c:85-86). Hvorvidt modellen gir en eksakt beskrivelse av faktiske, empiriske forhold, må vurderes ut fra typologiske og andre kontekstuelle data.

Gjennom funksjonene «phase» og «sequence» kalkulerer OxCal også en sannsynlig start og sluttfase for hver gruppering av modellerte dateringer. De mest sannsynlige start- og sluttfasene for de analyserte kontekstene er vist i figur 6, og jeg har gjort et forsøk på å lage en noe forenklet fremstilling av dette resultatet i figur 8, som sammenligner resultatet med periodeinndelingen til neolitikum, samt tolkningene av fasene på hver enkelt lokalitet. Her har jeg indikert med stiplede bokser en mulig yngre fase på Holeheia grunnet stilistiske likhetstrekk med materialet fra Logavik og Helganes, samt en eldre fase på Slettabø lag 2 på grunn av stilistiske likheter med eldre lokaliteter. Jeg har også lagt til den nye modellen for deponeringsforløpet i lag 3 på Slettabø, hvor dannelsen av sandlaget (3400-3200 f.Kr.) er markert med en boks med kryss over. Med denne nye modellen forutsetter vi at aktiviteten fortsatte etterpå, som vil si at fasen jeg har omtalt som «lag 3 på Slettabø» dermed ikke lenger er så nært knyttet til stratigrafisk lag 3 på lokaliteten. Med disse forholdene tatt i betraktning viser lokalitetene i figur 8 en relativt jevn spredning i tid, fra sent i tidligneolitikum til sen mellomneolitikum B. Som Brink (2009) har vist når det gjelder mellomneolitikum B (2800-2350 f.Kr.) i Sør-Sverige, er det lite trolig at de karakteristiske båtformede stridsøksene er stort eldre enn 2500 f.Kr. Han regner derfor båtøksene som ledeartefakter for perioden kalt sen mellomneolitikum B (2500-2200 f.Kr.). Av de her undersøkte lokalitetene er det Slettabø lag 2 som har sin primære brukstid i denne fasen, også muligens Helganes, men ingen båtøkser ble funnet på disse lokalitetene. 


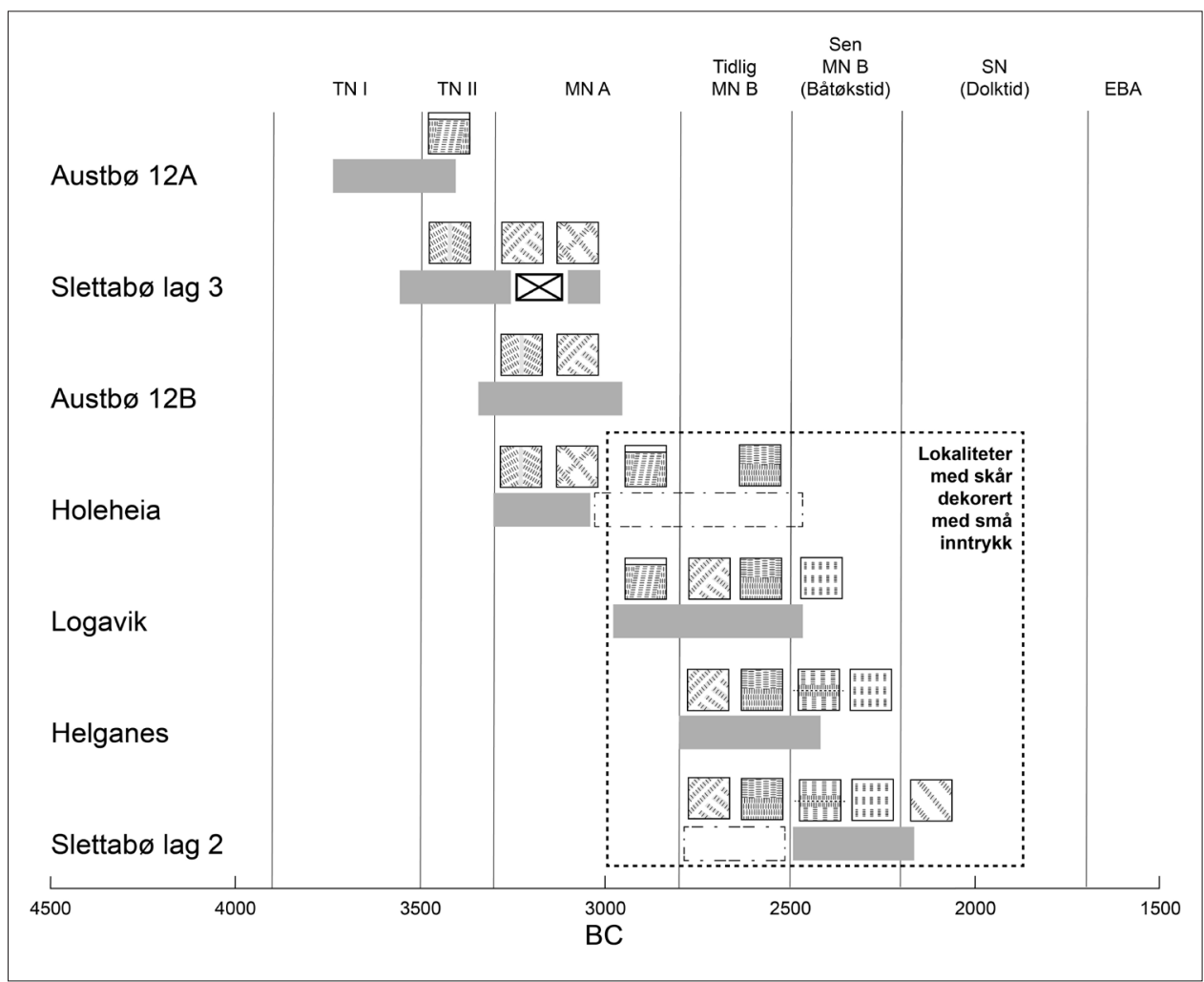

Figur 8. Tolkning av de modellerte fasene fra de undersøkte lokalitetene med dekorstiler av snorstempel, sammenlignet med periodeinndelingen av neolitikum. Fasene tar utgangspunkt $i$ medianverdien til de modellerte start- og sluttfasene. Stiplede bokser for Holeheia og Slettabø lag 2 viser til aktivitetsfaser indikert av resultatet av faseinndelingen og stilistiske likhetshetstrekk. Med små inntrykk vises det til koniske groper, bein (rørknokkel), negl, pinnestikk og kryss. Boksen med kryss over viser tidsspennet da det er trolig at sandlaget mellom lag 3 og 2 på Slettabø ble formet.

\section{Diskusjon}

Skårene med snorornamenter fra Austbø 12A og lag 3 på Slettabø, som trolig ble deponert i tidligneolittisk tid, fremstår som en samlet gruppe i det presenterte materialet fra Rogaland, også når man sammenligner med funn fra nærliggende regioner. Nå skal det sies at $\mathrm{i}$ alt dreier det seg om svært få skår dekorert med snor: ett fra Austbø 12A og seks fra Slettabø, samt to fra Kotedalen og syv fra Ramsvikneset i tidligere Hordaland fylke (Olsen 1992:141; Bakka 1993:49-50). Vi skal heller ikke glemme det ene skåret fra høyfjellslokaliteten Nordmannslågen 526, på Hardangervidda (Indrelid og Moe 1983). På Austbø 12A og Kotedalen er disse skårene dekorert med noe som ikke kan beskrives mer nøyaktig enn som horisontale render med snorinntrykk. Derimot har noen av skårene fra Slettabø, Ramsvikneset og Nordmannslågen 526 også vertikale render under randen som møter horisontale render 
og slik danner et lite parti med rutemønster, og dette er et velkjent mønster fra skår funnet på tidligneolittiske lokaliteter i Agder, i Oslofjord-området og i Øst-Sverige (Hallgren 2008:168; Schaller Åhrberg 2011; Sundström og Darmark 2013; Reitan 2014). Noen få skår fra Slettabø og Ramsvikneset er også dekorert med små inntrykk oppe på randen, som er kjent fra tidligneolittiske funn fra Oslofjord-området, slike som på Vøyenenga i Bærum (Østmo og Skogstrand 2006). De fleste skårene fra Vøyenenga ble funnet i gropen S47, hvorfra en kullprøve ble datert til 3704-3380 f.Kr. (T-17864, 4810 55 BP).

Det hersker med andre ord liten tvil om at krukker dekorert med snorinntrykk var i bruk på fangstboplasser både i Rogaland og i nærliggende områder i tidligneolittisk tid. Samtidig med disse skårene har man i Rogaland, og da på Austbø 12A og Slettabø lag 3, også snorstempelornerte skår. Det ene skåret fra Austbø 12A har snorstempel i samme utførelse som de snorornerte skårene med «rutenett» fra Slettabø, Ramsvikneset og Nordmannslågen 526. Som nevnt innledningsvis finnes det paralleller til den antatt eldste snorstempelornerte keramikken fra Slettabø på tidligneolittiske boplasser i Øst-Sverige. Videre viste korrespondanseanalysen at ulike versjoner av vinklet snorstempel (CS2-4) opptrer deretter, og at kortere snorstempel (CS6 og CS7/9) også kommer inn i mellomneolittisk tid. Snorstempel i kryssende render som former et skråstilt rutemønster (CS4) inntrer allerede i mellomneolitikum A (3300-2800 f.Kr.), og har faktisk størst geografisk utbredelse på Vestlandet. Det forekommer som nevnt i Kotedalen og på Holeheia, i lag 2 på Slettabø og på Auve i Sandefjord, og så vidt meg bekjent er den ikke å finne på lokaliteter lenger øst i landet.

At snorstempelorneringen plutselig forekommer noe sent i tidligneolittisk tid (3500-3300 f.Kr.) er et fenomen som er kjent i flere regioner av Sør-Skandinavia og i Øst-Sverige (Hallgren 2008; Sørensen 2014:115), og Østmo (2010) har argumentert overbevisende om at utførelsen av snorstempelet i Sør-Norge i denne perioden viser en likhet med tradisjonene i Øst-Danmark og Skåne (også kjent som Virum-stil, se Ebbesen og Mahler 1980). Nå skal det også sies at snorornering, inkludert det spesifikke rutemønsteret nevnt ovenfor fra lag 3 på Slettabø, Ramsvikneset og Nordmannslågen 526, også forekommer innenfor Virumstilen i disse traktene (Ebbesen og Mahler 1980:43, fig. 25.1; Koch 1998). Dette skulle kunne tilsi at skårene fra de tre nevnte lokalitetene ikke er stort eldre enn 3500 f.Kr., og dateringene av kull fra lag 3 på Slettabø stemmer forøvrig godt overens med denne tolkningen.

Starten på det tredje årtusenet f.Kr. markerer introduksjon av de små inntrykkene, nemlig koniske groper, negleinntrykk, bein (rørknokkel), pinnestikk og kryss. På grunn av allerede nevnte forhold på Holeheia, regner jeg det som sannsynlig at dette stiltrekket også tilhører den sene fasen, som ikke er representert i dateringene. Små inntrykk er kjent fra flere lokaliteter i Agder og på Østlandet (Nielsen m.fl. 2019), men er svært sjeldne lenger nord på Vestlandet. Skår med koniske groper forekom i Kotedalen (Olsen 1992:135), og noen få skår dekorert med små kryss, eventuelt linjer i sikksakk, samt pinnestikk, ble funnet på Ramsvikneset (Bakka 1993:49-50).

Nå som Beckers «skønne Dag» er her, og den neolittiske keramikken fra Rogaland har kommet for dagen, ser vi at det er en kobling til Jylland i tidligneolittisk tid, men den går ikke sjøveien direkte over Skagerrak, men derimot via vestkysten av Sverige, Oslofjorden og langs Agder (Sørensen 2014:223). Sporene i Rogaland fra denne tidlige prosessen er få, og keramikken ser først ut til å bli utbredt etter 3500 f.Kr., og fra tidlig av er det da primært fra Øst-Danmark og Skåne at impulsene har kommet fra. 
Jeg skal ikke gå nærmere inn på spørsmålet om økonomisk orientering i denne perioden, altså siste del av tidligneolittisk tid og gjennom mellomneolitikum, men det er riktignok noen få og til tider omdiskuterte funn som indikerer en dreining mot jordbruk og fehold også på Vestlandet. Fra Stangelandshelleren i Rogaland foreligger en tann fra tamdyr (trolig

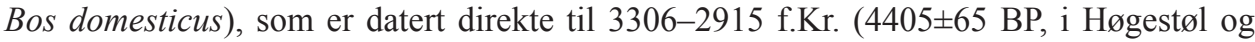
Prøsch-Danielsen 2006). I Kotedalen ble det blant annet dokumentert ti strukturer som inneholdt pollen fra korn (Hordeum, Triticum) og mulige indikatorer på beiting (Plantago lanceolata) i nærområdet, hvorav en av disse strukturene ble datert på trekull til 3319-2915 f.Kr. (4410 90 BP, struktur NS8 i Olsen 1992:266; pollenanalyse i Hjelle 1992:106). Det kan derfor synes sannsynlig at det ikke bare var keramikkhåndverket som kom til Rogaland og Vestlandet i denne perioden av steinalderen. Det er også interessant å bemerke at de her nevnte direkte daterte sporene etter dyrking og fehold opptrer like før den store de-neolitiseringen på Østlandet, altså en kollaps innen det første jordbrukssamfunnet, og som Erik Hinsch (1955) mente inntraff i mellomneolitikum fase III-IV (3000-2800 f.Kr.). Denne perioden synes å korrespondere med det reelle oppholdet i aktiviteten på Slettabø (mellom lag 3 og 2), samt den regionale overgangen fra produksjonen av krukker dekorert utelukkende med snor og snorstempel, til en mer kreativ variasjon av snorstempel og andre små inntrykk.

\section{Avslutning}

I denne artikkelen har jeg forsøkt å danne en kronologisk oversikt over de kontekstene fra Rogalands steinalder hvor det er funnet keramikk. Metoden jeg har anvendt, kalt fortolkende kronologi, har vist seg å være anvendelig på det studerte boplassmaterialet. Fordelen med denne tilnærmingen er kombinasjonen av tre ulike metoder som allerede er mer eller mindre godt etablerte $\mathrm{i}$ arkeologisk forskning, nemlig typologisk analyse, korrespondanseanalyse og modellering av radiokarbondateringer. Metoden er ikke utviklet spesielt med tanke på analyse av boplassdata fra steinalderen, slik vi kjenner dem fra Norge, men kan brukes på arkeologiske data fra både forhistorisk og historisk tid. De ni undersøkte neolittiske lokalitetene viser en utvikling i dekorative stiler fra sen tidligneolittisk tid og frem til senneolitikum. Forhåpentlig vil fremtidige studier kunne bruke samme metodiske tilnærming på boplassdata fra andre regioner innenfor det keramikkbrukende området av SørNorge i neolitikum.

\section{Litteratur}

Amundsen, Øystein M.

2000 Neolitikum i Agder og Telemark. En komparativ analyse av keramikk og flintøkser. Hovedfagsoppgave i nordisk arkeologi, IAKK, Det historisk-filosofiske fakultet, Universitetet i Oslo, Oslo.

Arnold, Dean E.

1985 Ceramic Theory and Cultural Process. Cambridge University Press, Cambridge.

Bakka, Egil

1993 Ramsvikneset - a Sub-Neolithic dwelling place in western Norway. Arkeologiske skrifter fra Historisk Museum 7:21-69. 
Bang-Andersen, Sveinung.

1981 En fangstboplass på Eigerøy - boplassbruk og miljøtilpasning $i$ sørvestnorsk yngre steinalder. AmS-Skrifter 6, Arkeologisk museum i Stavanger, Stavanger.

Bayes, Thomas R.

1763 An essay towards solving a problem in the doctrine of chances. Philos. Trans. R. Soc. 53:370 418.

Bayliss, Alex

2015 Quality in Bayesian chronological models in archaeology. World Archaeology 47:677-700.

Bayliss, Alex, Christopher Bronk Ramsey, Johannes van der Plicht og Alasdair Whittle

2007 Bradshaw and Bayes: Towards a Timetable for the Neolithic. Cambridge Archaeological Journal 17(1):1-28

Bayliss, Alex, John Hines og Karen Høilund Nielsen

2013a Interpretative chronologies for the male graves. I Anglo-Saxon Graves and Grave Goods of the 6th and 7th Centuries AD: A Chronological Framework, redigert av John Hines og Alex Bayliss, s. 231-338. The Society for Medieval Archaeology Monograph 33, Charlesworth Press, London.

2013b Interpretative chronologies for the female graves. I Anglo-Saxon Graves and Grave Goods of the 6th and 7th Centuries AD: A Chronological Framework, redigert av John Hines og Alex Bayliss, s. 339-454. The Society for Medieval Archaeology Monograph 33, Charlesworth Press, London.

Bayliss, Alex, Gerry McCormac, Michelle Thompson og John Hines

2013c Dating methods and their modelling, I Anglo-Saxon Graves and Grave Goods of the 6th and 7th Centuries AD: A Chronological Framework, redigert av John Hines og Alex Bayliss, s. 33-88. The Society for Medieval Archaeology Monograph 33, Charlesworth Press, London.

Becker, Carl-Johan

1947 Mosefundne lerkar fra Yngre Stenalder. Aarbøger for Nordisk Oldkyndighed og Historie 1947:1-318.

Bjørlykke, Knut O.

1908 Jcederens geologi. Norges Geologiske Undersøkelse No 48, Aschehoug \& Co, Kristiania.

Brink, Kristian

2009 I palissadernas tid. Om stolphål och skärvor och sociala relationer under yngre mellanneolitikum. Malmö Museer, Malmö.

Bronk Ramsey, Christopher

1995 Radiocarbon calibration and analysis of stratigraphy: the OxCal program. Radiocarbon $37: 425-430$.

2018 OxCal 4.3 Manual. Elektronisk dokument, C14.arch.ox.ac.uk/oxcal.html, sist besøkt 4. mars 2021.

2021 OxCal v4.4. Elektronisk dokument, C14.arch.ox.ac.uk/oxcal/OxCal.html, sist besøkt 4. mars 2021.

Brøgger, Anton Wilhelm

1909 Den arktiske stenalder $i$ Norge. Videnskabs-Selskabets Skrifter II, Historisk filosofisk klasse, A. W. Brøgger bogtrykkeri, Christiania.

Buck, Caitlin E. og Bo Meson

2015 On being a good Bayesian. World Archaeology 47:567-584.

Buck, Caitlin E., Litton, Clifford D. og Adrian F. M. Smith

1992 Calibration of radiocarbon results pertaining to related archaeological events. Journal of Archaeological Science 19(5):497-512.

Clarke, David

1968 Analytical Archaeology. Methuen, London.

Davidsen, Karsten

1978 The Final TRB Culture in Denmark. A Settlement Study. Institute of Prehistoric Archaeology, University of Copenhagen, Copenhagen. 
Dugstad, Sigrid A., Grethe M. Pedersen, Christin E. Jensen og Mia Lampiãinen-Avci

2018 Steinalderboplasser på Kvitsøy. Arkeologiske og naturvitenskapelige undersøkelser av fire steinalderboplasser på Kvitsøy Gnr. 16, Bnr. 2/5, Kvitsøy kommune. Arkeologisk museum, Universitetet i Stavanger, Stavanger.

Ebbesen, Klaus

1980 En oldtidshøj ved Systofte. Lolland-Falsters Stiftsmuseum 1980:13-33.

Ebbesen, Klaus og Ditlev Mahler

1980 Virum. Et tidligneolitisk bopladsfund. Aarbøger for nordisk oldkyndighed og historie 1979:1161.

Edenmo, Roger, Mats Larsson, Bengt Nordqvist og Eva Olsson

1997 Gropkeramikerna - fanns de? Materielle kultur och ideologisk förändring. I Regionalt och interregionalt. stenåldersundersökningar i Syd-och Mellansverige, redigert av Mats Larsson og Eva Olsson, s. 135-213. Riksantikvarieämbetet, Arkeologiska undersökningar, Skrifter nr. 23, Stockholm.

Furholt, Martin

2019 Re-integrating archaeology: A contribution to aDNA studies and the migration discourse on the $3^{\text {rd }}$ millennium BC in Europe. Proceedings of the Prehistoric Society 85:115-129.

Gjessing, Helge

1914 Fra Jæderens stenalder. Oldtiden 4:43-56.

1920 Rogalands stenalder. Stavanger Museum, Dreyer, Stavanger.

Glob, Peter V.

1952 Danske Oldsager II. Yngre Stenalder. Gyldendalske Boghandel, København.

Glørstad, Håkon

1996 Neolittiske smuler. Små teoretiske og praktiske bidrag til debatten om neolittisk keramikk og kronologi i Sør-Norge. Varia 33, Universitetets Oldsaksamling, Oslo.

2006 Neolittisk Renessanse. Hypoarkeologiske Tekster om Neolitikum i Sør-Norge. Oslo arkeologiske serier nr. 4, Oslo Academic Press og IAKH, Oslo.

2009 The Northern Province? The Neolithisation of Southern Norway I Neolithisation as of History Mattered. Processes of Neolithisation in North-Western Europe, redigert av Håkon Glørstad og Christopher Prescott, s. 135-168. Bricoleur Press, Lindome.

Glørstad, Håkon og Lars Sundström

2014 Hamremoen - an enclosure for the hunter-gatherers?, I Landscapes, Histories and Societies in the Northern European Neolithic, redigert av Martin Furholt, Martin Hinz, Doris Mischka, Gordon Noble og Deborah Olausson, s. 29-48. Frühe Monumentalität und soziale Differenzierung 4. Institut für Ur- und Frühgeschichte der CAU Kiel, Kiel.

Glørstad, Håkon og Steinar Solheim

2015 The Hamremoen enclosure in southeastern Norway. An exotic glimpse into the process of Neolithization. I Neolithic Diversities. Perspectives from a Conference in Lund, Sweden, redigert av Kristian Brink, Susan Hydén, Kristina Jennbert, Lars Larsson og Deborah Olausson, s. 139-152. Acta Archaeologica Lundensia Series in $8^{\circ}$, No 65. Lund University, Lund.

Gulliksen, Steinar, Reidar Nydal og Fred Skogseth

1978 Trondheim natural radiocarbon measurements VIII. Radiocarbon 20(1):105-133.

Gustafson, Gabriel

1899 En stenalders boplads paa Jæderen. Bergens Museums aarbog 1, Bergen.

1906 Norges oldtid. Mindesmcerker og oldsager. Centraltrykkeriet, Kristiania.

Hallgren, Fredrik

2008 Identitet i praktik. Lokala, regionala och överregionala sociala sammanhang inom nordlig trattbägarkultur. Coast to coast, Uppsala.

Hinsch, Erik

1955 Traktbegerkultur - megalitkultur. En studie av Øst-Norges eldste, neolitiske gruppe.

Universitetets Oldsaksamlingens årbok 1951-1953:10-177. 
Hjelle, Kari Loe

1992 Pollenanalytiske undersøkelser innenfor boplassen på Kotedalen. I Kotedalen - en boplass gjennom 5000 år. Bind 2. Naturvitenskapelige undersøkelser, redigert av Kari Loe Hjelle, Anne Karin Hufthammer, Peter Emil Kaland, Asle Bruen Olsen og Eli Christine Soltvedt, s. 91-122. Historisk museum, Universitetet i Bergen, Bergen.

Høgestøl, Mari og Lisbeth Prøsch-Danielsen

2006 Impulses of agro-pastoralism in the 4th and 3rd millennium BC on the south-western coastal rim of Norway. Environmental Archaeology 11(1):19-34.

Ingstad, Anne S.

1965 Sluppan. En fangstboplass fra yngre steinalder i Telemark. II. Oldsaksmaterialet. Viking XXIX:83-112.

1970 Steinalderboplassen Rognlien i Eidanger. Et bidrag til belysning av yngre steinalder i Telemark. Universitetets Oldsaksamligens årbok 1967-1968:19-142.

Jaksland, Lasse

2005 Hvorfor så mange økser? En tolkning av funnene fra den klassiske Nøstvetboplassen i As, Akershus. Hovedfagsoppgave i nordisk arkeologi våren 2005, IAKH, Det humanistiske fakultet, Universitetet i Oslo, Oslo.

Juhl, Kirsten

2001 Austbø på Hundvåg gennem 10000 år. Arkceologiske undersøgelser i Stavanger kommune 1987-1990. Rogaland, Syd-Vest Norge. AmS-Varia 38. Arkeologisk museum i Stavanger, Stavanger.

Koch, Eva

1998 Neolithic Bog Pots from Zealand, Møn, Lolland and Falster. Det Kongelige Nordiske Oldskriftselskab, Copenhagen.

Lindblom, Inge

1982 Økologi og økonomi for deler av Sør-Jæren i sen-neolitikum. Del 1. Rugland - en sen-neolitisk boplass på Jæren, Sørvest-Norge. I Faggrenser brytes. Artiklar tileigna Odmund Møllerup 7. desember 1982, redigert av Arnvid Lillehammer, s. 15-32. AmS-Skrifter 9. Arkeologisk museum i Stavanger, Stavanger.

Litton, Clifford D. og Caitlin E. Buck

1995 The Bayesian Approach To the Interpretation of Archaeological Data. Archaeometry 37:1-24.

Løken, Trond

1977 Utgravninger i Randaberg. Frá haug ok heiðni 3:225-236.

Madsen, Torsten

1990 Seriation and multivariate statistics. I Computer Applications and Quantitative Methods in Archaeology, redigert av Sebastian Rahtz og Julian Richards, s. 205-214. British Archaeological Reports S548, Oxford.

2014 CAPCA. Elektronisk dokument, Archaeoinfo.dk, sist besøkt 4. mars 2021.

Mangerud, Jan, Stein Bondevik, Steinar Gulliksen, Anne K. Hufthammer og Tore Høisæter

2006 Marine 14C reservoir ages for 19th century whales and molluscs from the North Atlantic.

Quaternary Science Reviews 25:3228-3245.

Nielsen, Svein V.

2020 Wave? What wave? Testing for impact of the Garth tsunami (3500 BCE) on Neolithic coastal settlements in Western Norway. Journal of Archaeological Science Reports 33:102464.

Nielsen, Svein V., Per Persson og Steinar Solheim

2019 De-Neolithisation in southern Norway inferred from statistical modelling of radiocarbon dates. Journal of Anthropological Archaeology 53:82-91.

Nummedal, Anders og Anathon Bjørn 1930 Boplassfund fra yngre stenalder i Aust-Agder. Universitetets Oldsaksamlingers årbok 3:21-109.

Nydal, Reidar, Knut Løvseth, Kari E. Skullerud og Marianne Holm

1964 Trondheim natural radiocarbon measurements IV. Radiocarbon 6:280-290. 
Olsen, Asle B.

1992 Kotedalen - en boplass gjennom 5000 år. Fangstbosetning og tidlig jordbruk i vestnorsk steinalder: Nye funn og nye perspektiver. Historisk Museum, Universitetet i Bergen, Bergen.

Philippsen, Bente

2012 Variability in Freshwater Reservoir Effect. Implications for Radiocarbon Dating of Prehistoric Pottery and Organisms from Estuarine Environments. PhD Thesis, Aarhus.

2013 The freshwater reservoir effect in radiocarbon dating. Heritage Science 1:24.

Reimer, Paula.J., Willaim E. Austin, Edouard Bard, Alex Bayliss, Paul G. Blackwell, Christopher Bronk Ramsey, Martin Butzin, Hai Cheng, R. Lawrence Edwards, Michael Friedrich, Pieter M. Grootes, Thomas P. Guilderson, Irka Hajdas, Timothy J. Heaton, Alan G. Hogg, Konrad A. Hughen, Bernd Kromer, Sturt W. Manning, Raimund Muscheler, Jonathan G. Palmer, Charlotte Pearson, Johannes Van Der Plicht, Ron W. Reimer, David A. Richards, E. Marian Scott, John R. Southon, Christian S. M. Turney, Lukas Wacker, Florian Adolphi, Ulf Büntgen, Manuela Capano, Simon M. Fahrni, Alexandra Fogtmann-Schulz, Ronny Friedrich, Peter Köhler, Sabrina Kudsk, Fusa Miyaki, Jesper Olsen, Frederick Reinig, Minoru Sakamoto, Adam Sookdeo, Sahra Talamo

2020 The IntCal20 nothern hemisphere radiocarbon age calibration curve $(0-55 \mathrm{cal} \mathrm{kBP})$.

Reitan, Gaute Radiocarbon 62(4):725-757.

2014 Langangen Vestgård 6. En strandbundet boplass med keramikk fra tidligneolitikum. I Vestfoldbaneprosjektet. Arkeologiske undersøkelser i forbindelse med ny jernbane mellom Larvik og Porsgrunn. Bind II. Seinmesolittiske, neolittiske og yngre lokaliteter i Vestfold og Telemark, redigert av Gaute Reitan og Per Persson, s. 171-220. Portal forlag og Kulturhistorisk Museum, Oslo.

Reitan, Gaute, Lars Sundström og Jo-Simon F. Stokke

2018 Grains of truth. Neolithic farming on Mesolithic sites. New insights into early agriculture in Southeast Norway. I The Stone Age Coastal Settlement in Aust-Agder, Southeast Norway. Archaeological Excavations Along the New E18 Tvedestrand-Arendal, redigert av Gaute Reitan og Lars Sundström, s. 521-539. Cappelen Damm Akademisk, Oslo.

Resi, Heid

1998 "Krukken i treet”. Om nye funn fra grav og boplass på Kjølberg i Østfold. I Fra Østfolds oldtid. Foredrag ved 25-årsjubileet for Universitetets arkeologiske stasjon Isegran, redigert av Einar Østmo, s. 55-68. Universitetets Oldsaksamlings Skrifter. Ny rekke nr. 21, Oslo.

Schaller Åhrberg, Eva

2011 Rapport arkeologisk utgravning. Boplass fra tidligneolitikum, bronsealder, jernalder. Haslum, 51/29, 33, 78, Frogn, Akershus. Kulturhistorisk Museum, Universitetet i Oslo, Fornminneseksjonen, Oslo.

Simonsen, Asbjørn, Inge Lindblom og Sverre Bakkevig

1982 Del 3. Ruglandboplassen belyst ved "Site-Territory"-analyse. I Faggrenser brytes. Artiklar tileigna Odmund Møllerup 7. desember 1982, redigert av Arnvid Lillehammer, s. 41-56.

AmS-Skrifter 9. Arkeologisk museum i Stavanger, Stavanger.

Skandfer, Marianne

2005 Early northern comb ware in Finnmark: The concept of Säräisniemi 1 reconsidered. Fennoscandia Archaeology 12:3-27.

Skjølsvold, Arne

1977 Slettabøboplassen. Et bidrag til diskusjonen om forholdet mellom fangst- og bondesamfunnet i yngre steinalder og bronsealder. AmS-Skrifter 2, Arkeologisk musuem i Stavanger, Stavanger.

1980 Boplassen på Holeheia i Klepp. AmS-Varia 7, Arkeologiske museum i Stavanger, Stavanger.

Solberg, Anette

2015 Steinalderliv på Helganes. Arkeologiske undersøkelser av en mellomneolittisk boplass i skjcringspunktet mellom nord og sør. AmS-Varia 56, Arkeologisk museum, Universitetet i Stavanger, Stavanger. 
Steier, Peter og Werner Rom

2000 The use of Bayesian statistics for $14 \mathrm{C}$ dates of chronologically ordered samples: A critical analysis. Radiocarbon 42:183-198.

Stoltenberg, Emil A.

2017 Frekventisme, Bayes og likelihoodprinsippet. Filosofisk supplement 2:58-65.

Strinnholm, Anders

2001 Bland säljägare och fårfarmare. Struktur och förändring i Västsveriges mellanneolititikum. Kust till kust böcker nr. 4, Uppsala.

Sundström, Lars og Kim Darmark

2013 Rapport arkeologisk utgravning. Steinalderlokalitet. Hamremoen av Hamre, 98/6, 293,

Kristiansand kommune, Vest-Agder. Kulturhistorisk Museum, Universitetet i Oslo,

Fornminneseksjonen, Oslo.

Sørensen, Lasse

2014 From Hunter to Farmer. Acta Archaeologica 85:1-305.

Østmo, Einar

1993 Hellerbosetning i østnorsk yngre steinaldern. Utgravningen av Sandtrahelleren i Tjølling, Larvik, Vestfold. Universitetets Oldsaksamlings årbok 1991-1992:87-102.

2004 En fangstboplass fra yngre steinalder på Solbakken i Idd, og en uventet elgskulptur. Et notat. Viking LXVII:35-48.

2008 Auve. En fangstboplass fra yngre steinalder på Vesterøya i Sandefjord. Norske oldfunn XXVIII. Kulturhistorisk museum, Oslo.

2010 The Cord Stamp in Neolithic Scandinavia. Acta Archaeologica 81, 44-71.

Østmo, Einar og Lisbeth Skogstrand

2006 Nye funn av traktbegerkeramikk fra Oslofjorden. Børsebakke og Vøyenenga. Viking LXIX:6990. 